
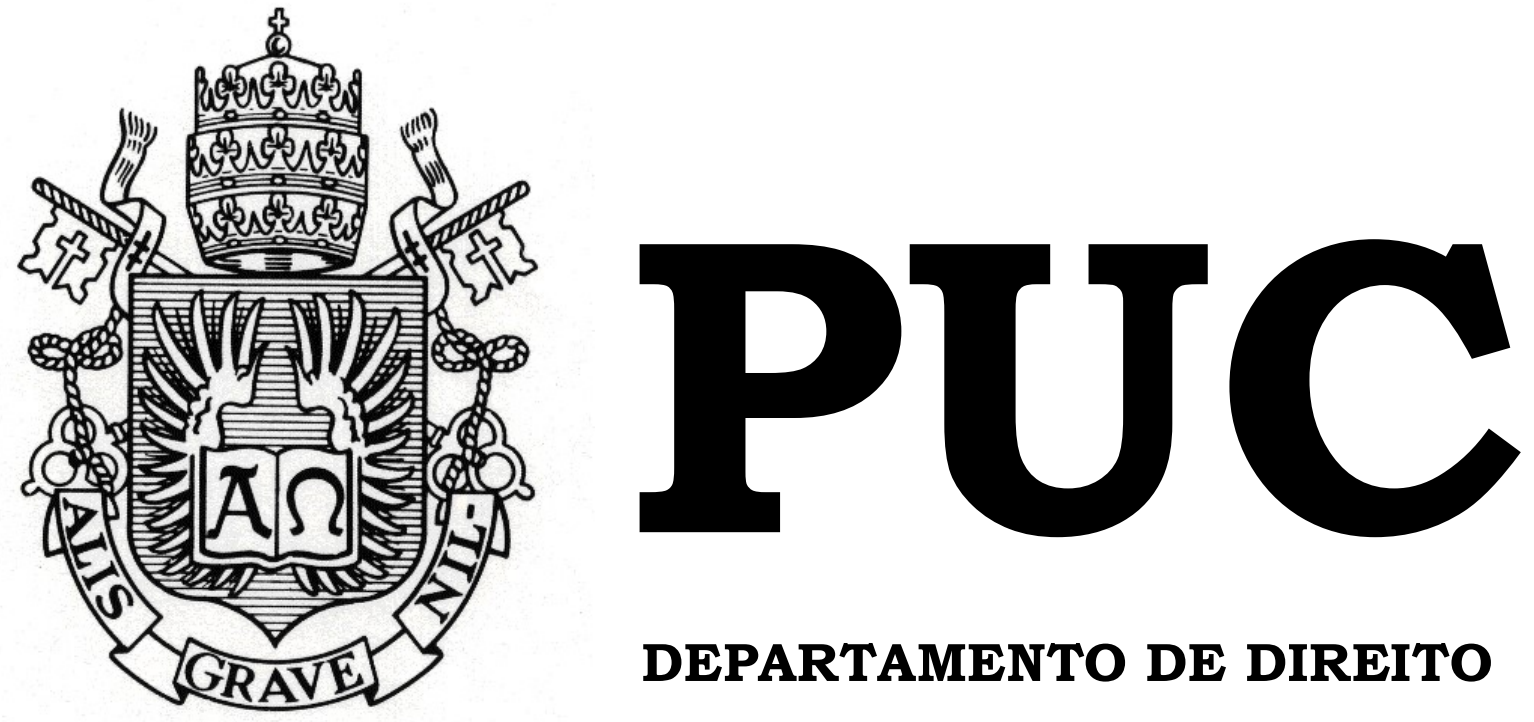

DEPARTAMENTO DE DIREITO

A Reponsabilidade do Gestor de Fundo de Investimentos

por

CAIO AGIB FERNANDES PEREIRA

ORIENTADORA: NORMA JONSSEN PARENTE

2019.1 
PONTIFÍCIA UNIVERSIDADE CATÓLICA DO RIO DE

JANEIRO

RUA MARQUÊS DE SÃO VICENTE, 225 - CEP 22453-900

RIO DE JANEIRO - BRASIL

\section{A Reponsabilidade do Gestor de Fundo de Investimentos}

por

CAIO AGIB FERNANDES PEREIRA

Monografia apresentada ao Departamento de Direito da Pontifícia Universidade Católica do Rio de Janeiro (PUC-Rio) para a obtenção do Título de Bacharel em Direito.

Orientadora:

Norma Jonssen Parente 
Faz o que for justo. O resto virá por si só.

Johann Wolfgang von Goethe 


\section{AGRADECIMENTOS}

Aos meus pais pela paciência, e à Professora Norma pelo exemplo e por todo apoio. 


\section{RESUMO}

O presente estudo tem como objetivo expor o papel do gestor de fundo de investimentos não estruturados à luz das legislações que regulamentam seu ofício, e analisar os deveres e responsabilidades próprios de sua atuação na condição de condutor da estratégia de investimentos do fundo de investimentos.

Para isto, foram examinadas as instruções produzidas pela Comissão de Valores Mobiliários (I-CVM n 555 e I-CVM nº558, respectivamente, "ICVM 555 e ICVM 558”), os princípios que regem os deveres dos administradores de conselhos de sociedades anônimas de acordo com a Lei no 6.404/1976 (Lei das S.A.) e a doutrina e jurisprudência produzidas sobre o tema no Brasil.

Por fim, tratou-se também de buscar entender o tipo de responsabilidade pertinente a este agente e suas consequências de um ponto de vista prático.

Palavras Chave: fundos de investimento - deveres do gestor - responsabilidade do gestor - dever de diligência - dever de boa-fé - dever de diligência - dever de lealdade - duty of dilligence - duty of loyalty - business judgment rule mercado de capitais - Comissão de Valores Mobiliários - gestão de fundos de investimento. 


\section{SUMÁRIO}

\section{INTRODUÇÃO}

\section{DAS ORIGENS HISTÓRICAS DO FUNDO DE INVESTIMENTOS}

1.1 Trust funds

1.2 Os fundos de investimentos brasileiros

\section{REGULAÇÃO E AUTORREGULAÇÃO DOS FUNDOS DE} INVESTIMENTOS

2.1 A Comissão de Valores Mobiliários - CVM

2.2 Associação Brasileira das Entidades dos Mercados Financeiros de Capitais - ANBIMA

\section{LEGISLAÇÃO BRASILEIRA APLICÁVEL AOS FUNDOS DE} INVESTIMENTO

3.1 ICVM 555 e ICVM 558

3.2 Lei das S.A. (Lei n ${ }^{0}$ 6.404/1976)

3.3 Código ANBIMA de regulação e melhores práticas de fundos de investimentos

\section{COMPETÊNCIAS E RESPONSABILIDADES DOS GESTORES DOS FUNDOS DE INVESTIMENTOS}

4.1 Esclarecimentos acerca das funções de administrador e gestor

4.2 Deveres do gestor

4.2.1 Dever de se qualificar

4.2.2 Dever de bem administrar e dever de se informar

4.2.3 Dever de se informar e dever de transparência

4.2.4 Dever de se investigar e dever de vigiar

4.2.5 Dever de lealdade

4.3 Os deveres de diligência e de lealdade e o modelo norte-americano do bussiness judgement rule

$4.4 \mathrm{O}$ regulamento do fundo e a política de investimentos

\section{RESPONSABILIZAÇÃO DO GESTOR DO FUNDO DE} INVESTIMENTOS

5.1 Noções introdutórias à responsabilidade civil no direito brasileiro 5.1.1 Tipos de obrigação: obrigação de meio X obrigação de fim 5.2 Responsabilidade do gestor - ICVM 555, 558 e Lei das S.A.

5.3 Da relação de consumo na aquisição de quotas de fundo de investimento

5.4 Jurisprudência sobre a responsabilidade do gestor de fundos de investimento 
CONCLUSÃO

BIBLIOGRAFIA 


\section{INTRODUÇÃO}

Atualmente o mercado financeiro é composto por uma farta diversidade de tipos de investimentos. O cidadão comum pode escolher entre opções de investimentos de acordo com sua disposição para com os diferentes graus de exposição a riscos envolvidos.

Os mais avessos podem optar por investimentos de renda variável como títulos do tesouro direto (Letras do Tesouro Nacional - LTN, Letras Financeiras do Tesouro - LFT e Notas do Tesouro Nacional série B - NTNB) Certificados de Depósito Bancário (CDB) ou debêntures, para citar alguns exemplos. Enquanto os mais dispostos a arriscar podem escolher investir em ações de companhias listadas na bolsa, venture capital ou operações mais complexas envolvendo circunstâncias futuras do mercado.

Apesar da facilidade de se investir, com acesso a ampla gama de informações públicas envolvendo os mais variados ativos, todos as opções citadas requerem, ao menos, um nível mínimo de conhecimento do investidor. Sendo essa expertise diretamente proporcional ao grau de risco do ativo e de sofisticação da operação que o envolve.

Logo, os riscos elevados são intrínsecos aos investimentos com potencial de rentabilidade extraordinária, que, ao revés, podem resultar em prejuízos que variam desde retornos muito aquém do esperado até a perda de parcela do capital investido. Além disso, certas oportunidades de investimento só estão disponíveis a investidores que possuem um valor elevado de capital, e exigem o monitoramento constante de variáveis que podem impactar o investimento e definir o seu momento ideal de saída ou de permanência. 
Por óbvio, nem todos os poupadores que desejam se aventurar no mercado financeiro são investidores profissionais. Ao contrário, em grande parte são assalariados em geral que almejam retornos positivos a fim de incrementar seu patrimônio ou viabilizar uma aposentadoria mais confortável. Logo, possuem suas rotinas de trabalho e muitas vezes não dispõem do tempo nem da expertise necessária para executar tais investimentos.

É nesse espaço que se inserem os fundos de investimentos, como veículos de que permitem a comunhão de recursos de diversos investidores que confiam a um gestor competente a responsabilidade de gerenciar a carteira de valores do fundo em busca de retornos relevantes. Assim, ao adquirir quotas de um fundo de investimento, o investidor é atraído pela especialização do gestor e a sua exclusividade na gestão do fundo.

O mercado de fundos de investimento no Brasil tem se desenvolvido bastante nas duas últimas décadas, surgindo fundos das mais variadas espécies de ativos e diferentes estratégias de investimentos. Nessa perspectiva, faz-se fundamental avaliar os deveres e a responsabilidade do gestor na sua relação fiduciária para com os quotistas e o fundo como um todo.

Dessarte, o intuito do presente estudo é analisar a responsabilidade dos gestores dos sete tipos de fundos de investimento abrangidos pela ICVM 555/2014. Porém, não estão abrangidas nesta análise as peculiaridades das regras de gestão dos fundos denominados estruturados, como os regidos pelas instruções de nos. 356, 444, 472, 579; e 398.

Nada obstante, as regras gerais extraídas da legislação e jurisprudência sobre a boa gestão devem, em sua maioria, ser observadas pelos gestores de todas as espécies de fundos de investimento. 


\section{DAS ORIGENS HISTÓRICAS DO FUNDO DE INVESTIMENTOS}

\subsection{Trust Funds}

Apesar de os fundos de investimento terem passado por diversos estágios até alcançarem a sua forma atual, a maior parte de sua estrutura original foi conservada. Essencialmente, um fundo de investimentos é um instrumento de investimento coletivo que permite a união de capital de diversos investidores que não possuem affectio societatis entre si - em favor da delegação da gestão desses recursos a um terceiro, o gestor.

A estrutura dos primeiros fundos de investimentos é muito próxima de seus antecessores, os investiment trusts, muito utilizados na Europa desde o século XVIII como forma coletiva de investimento; nessa modalidade, os investidores indicavam um trustee para gerir seu patrimônio.

Não é possível precisar exatamente quando e onde surgiu a estrutura que teria servido de base para os fundos de investimentos modernos; porém, segundos pesquisadores, sua forma inicial, como pool de investimentos, teria ocorrido na República das Sete Províncias dos Países Baixos - cuja área compreendia parte da Holanda e Bélgica atuais - em meados do século XVII. Os neerlandeses, exímios navegadores, já haviam colhido os frutos da sua Idade de Ouro, e, por consequência, criado um terreno fértil para o desenvolvimento de estruturas de investimento de capitais. A cidade de Amsterdam, por exemplo, já era sede de uma bolsa de valores (Amsterdam Exchange) que contava com mais de mil tipos de valores mobiliários. ${ }^{1}$

\footnotetext{
1 ROUWENHORS, K. Geert. The Origins of Mutual Funds. Disponível em: $<$ https://poseidon01.ssrn.com/delivery.php?ID $=88212306611700708406403000001600310401703706$ $\underline{4079033004076089089068090122087006127000036041017035040124044004123067002069000046}$ $\underline{0260330390410980700270001111231060560440200051171270691260201140960850950151011150}$ $\underline{04066103106116103013126026106078100105 \& \mathrm{EXT}=\mathrm{pdf}>}$. Acesso em 02.06.2019
} 
A ideia central era a junção da força de capital de diversos investidores buscando viabilizar uma estrutura de investimento coletivo que permitisse a diversificação de investimentos e redução de riscos para os investidores. Assim, o primeiro fundo teria surgido quando o comerciante Abraham van Ketwich ofereceu ao mercado duas mil cotas para subscrição do seu fundo, sob o nome simbólico de "Unity Creates Strenght" ("A Unidade Cria a Força”). Esgotadas as vendas das duas mil cotas disponibilizadas aos primeiros quotistas, o ingresso no fundo só poderia ocorrer no mercado secundário, ou seja, através da compra de cotas dos investidores primários.

\subsection{Os fundos de investimentos brasileiros}

O primeiro fundo brasileiro que se tem notícia data de 1952, o fundo Crescinco do empresário e político norte-americano Nelson Rockefeller, seguido do Valéria Primeira da Deltec em 1961, empresa do investidor Dauphinot Jr. Eventualmente a International Basic Economic Corporation (IBEC), dona do Crescinco, viria a se "fundir" com a Deltec e o Banco Moreira Salles, dando origem ao Banco de Investimentos do Brasil (BIB), companhia que teve atuação significativa no fomento do mercado financeiro brasileiro pós edição da Lei de Mercado de Capitais (1965).

Todavia, as décadas seguintes não desfrutaram de um crescimento expressivo da indústria de fundos de investimento, de maneira que eles começam a ganhar força a partir de 1994. Com a implementação do Plano Real e a consolidação de uma moeda nacional forte, vieram os sinais positivos de estabilidade da economia: taxas de juros e inflações mais comportadas. Antes disso, o investidor preferia investir em títulos de renda fixa, que se provavam mais rentáveis e muito menos arriscados, uma vez que as variações da taxa de inflação desestimulava outros tipos de investimentos por dificultar os cálculos 
de previsões de retorno. Assim, à época, o mercado de fundos de investimentos apresentava apenas duas alternativas: fundos de renda fixa ou fundos de ações.

A partir do Plano Real a estabilidade econômica passou a permitir um mínimo de previsibilidade, viabilizando os investimentos em renda variável. Nota-se uma diversificação das opções de investimentos disponíveis no mercado de capitais. Na mesma época são realizadas as privatizações de empresas estatais de setores antes considerados estratégicos, pelo governo de Fernando Henrique Cardoso. É nesse ambiente que despontam os fundos de algumas das gestoras mais tradicionais do país, como a Verde Asset, Dynamo e a Tempo Capital.

Até recentemente (26.07./2017) o mercado de renda fixa brasileira gozava de juros na casa de dois dígitos -- entre os anos de 2015 e 2016 a SELIC chegou a ficar estagnada em 14,25\% por mais de 14 meses. O investimento nos ativos desta espécie, ante aos riscos baixos, ainda representavam um bom negócio para o investidor médio. 
Atualmente com mínimas históricas para as taxas de juros futuros e viés de baixa para a taxa SELIC (hoje em 6,5\% ao ano), é provável que nos próximos anos o mercado diversifique ainda mais seus investimentos em renda variável, em vez de correr o risco de obter retornos reais baixíssimos em ativos de renda fixa atrelados à SELIC.

O gráfico abaixo apresenta um panorama histórico de diversificação das categorias dos fundos de 1984 até o presente ano, evidenciando o surgimento de novas categorias e o aumento significativo da presença dos fundos no mercado financeiro brasileiro e do volume de capital por eles geridos.

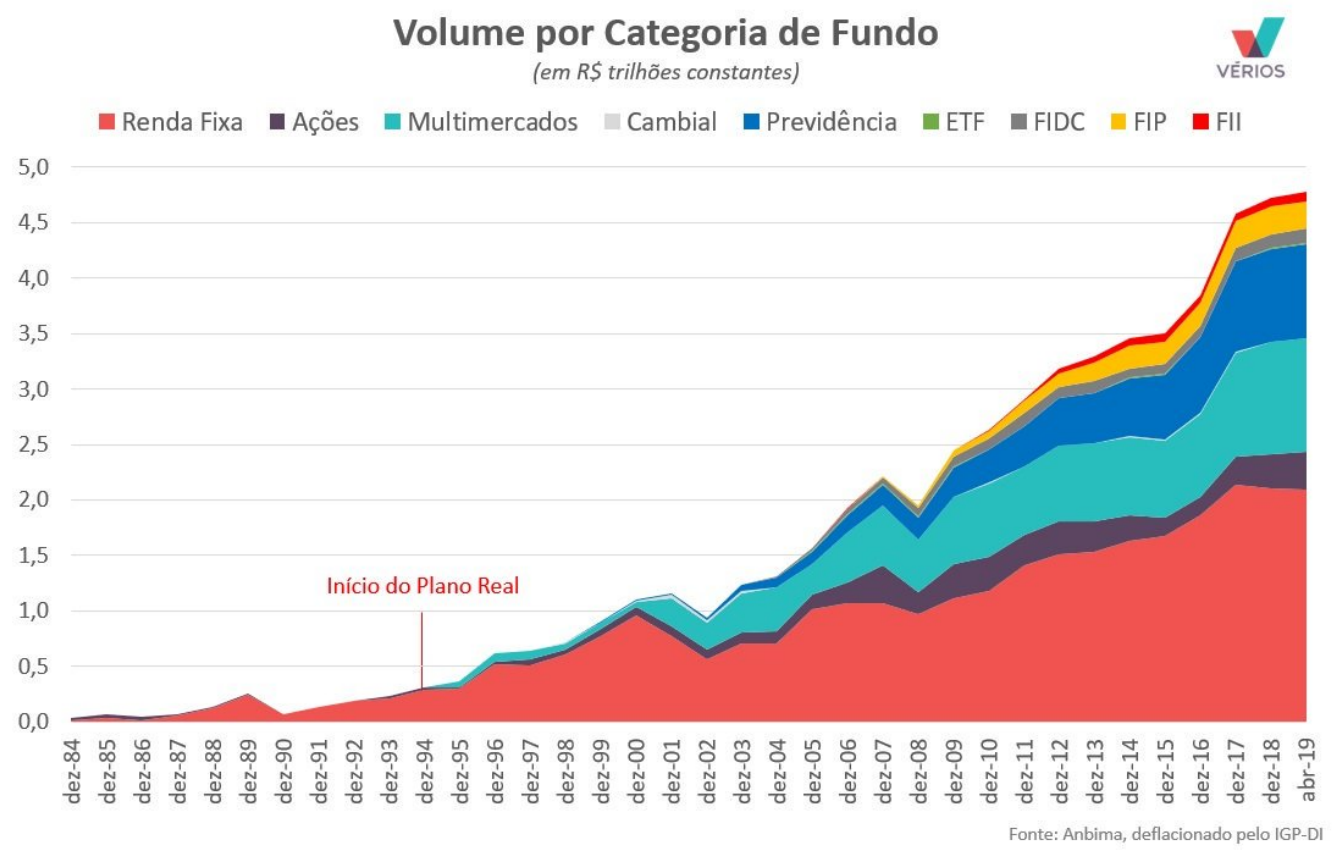




\section{REGULAÇÃO E AUTORREGULAÇÃO DOS FUNDOS DE INVESTIMENTO}

\subsection{A COMISSÃO DE VALORES MOBILIÁRIOS - CVM}

Para uma correta abordagem dos aspectos relativos à conceptualização de valores mobiliários e da criação da Comissão de Valores Mobiliários, é necessário apresentar, ainda que brevemente, o contexto econômico brasileiro à época de sua criação, bem como seus desdobramentos sobre os investimentos disponíveis e a disposição do mercado financeiro como um todo.

Em 1956, o Produto Interno Bruto (PIB) brasileiro havia caído de 8,8\% (1955) para 2,9\%, quando o então Presidente Juscelino Kubitschek propôs o Plano de Metas formulado por Roberto Campos, visando retomar o crescimento econômico do país mediante a implementação de uma série de medidas de investimento direto e de estímulo à indústria e a obras de infraestrutura no país. Impulsionado por financiamentos públicos e geração de empregos, o PIB do brasil voltou a crescer, alcançando 10,8\% em 1958 e decrescendo a passos largos, até chegar a pífios 0,6\% em 1963.

O país passava na década de 1960 por uma crise econômica, com a inflação anual sempre acima de 30\% (chegando a 92,1\% em 1964). Assim, os poupadores almejavam evitar a perda de seu poder aquisitivo, fugindo da corrosão inflacionária.

É nesse contexto que em 1964, com a entrada dos militares no poder, o governo de Henrique Castelo Branco, visando atender à necessidade de financiamento estatal, promulgou a Lei $\mathrm{n}^{\mathrm{o}} 4.357 / 1964$. A Lei autorizava o governo a emitir as chamadas Obrigações Reajustáveis do Tesouro Nacional (ORTNs), que seriam títulos da dívida pública pré e pós-fixados, com juros anuais de $6 \%$ sobre o valor aplicado e corrigido segundo o índice inflacionário. 
$\mathrm{Na}$ sequência, buscando reestruturar o mercado de financiamento privado, é decretada a Lei de Mercado de Capitais (Lei n ${ }^{\circ}$ 4.728/1965), um marco regulatório cujo objetivo principal era disciplinar o mercado de capitais no país e suas demandas crescentes.

Dentre os temas abrangidos por essa lei, valem citar os seguintes: a indicação de atribuições dos órgãos administrativos do mercado financeiro, dentre eles o Conselho Monetário Nacional (CMN) e o Banco Central (Bacen); a organização do sistema de distribuição do mercado, bem como de formas de acesso deste pelas empresas; o acesso de empresas estrangeiras ao mercado de capitais nacionais; as regras para emissão de títulos de dívida em geral e de ações; as formas de organização e as obrigações das sociedades anônimas; e as distinções entre sociedades de capital aberto e fechado.

Todavia, um dos artigos mais importantes da Lei $n^{0} 4.728$ talvez seja o terceiro, no qual se atribui ao Bacen a competência de registrar e fiscalizar as empresas listadas nas bolsas de valores do país, bem como as sociedades de investimento e instituições financeiras em geral que possuíssem objeto voltado para a revenda e distribuição de valores mobiliários. Também foi incumbida à autarquia o monitoramento de informações das companhias não divulgadas ao público. Sinteticamente, ao Bacen caberia a fiscalização do mercado de capitais, enquanto o CMN deveria regular o setor.

No artigo 50, tratou-se brevemente de alguns aspectos dos fundos de investimentos, mencionando a sua organização em formato de condomínio e delegando ao CMN a fixação do arcabouço normativo que deveria regulamentar o funcionamento dos mesmos. Já se adiantavam, porém, i) a obrigatoriedade de realização de "assembleia de condôminos" anual a fim de aprovar as contas dos administradores, e ii) a realização de auditoria das contas por auditor independente registrado junto ao Bacen.

A fundação da CVM ocorre em 1976 com a sanção da Lei n ${ }^{\circ}$ 6.385/1976. O mercado de ações brasileiro ainda era muito incipiente e desorganizado, e a 
demanda privada por um alargamento dos canais de investimentos em empresas de capital aberto não era acompanhada de um equivalente aprimoramento das "regras do jogo". Segundo Roberto Teixeira da Costa, ex-presidente e um dos fundadores da CVM, "todos queriam participar do mercado de ações de qualquer maneira, sem nenhuma orientação técnica e sem um mecanismo neutralizador que pudesse coibir excessos".2

Nos anais da Lei, apresentados pelo então ministro da fazenda Mario Henrique Simonsen, aponta-se como motivação de sua redação a criação de um ambiente equilibrado no mercado de capitais através do estabelecimento de regras claras para o seu funcionamento. Buscava-se, assim, transmitir confiança ao investidor privado, que desejava investir no Brasil mas se via prejudicado por riscos não inerentes aos negócios das empresas e aos fatores macroeconômicos.

A somar, o Bacen, cuja competência para fiscalizar o mercado havia sido atribuída pela Lei n ${ }^{o} 4.728 / 1965$, encontrava-se sobrecarregado por realizar, além de suas "novas" competências, suas funções originárias de gestão de moeda local, crédito e dívida pública.

Nesse sentido, a Lei de 1976 serviu não apenas para criar a CVM e definir suas atribuições, mas tratou de reformar a estruturação do mercado financeiro iniciada pela Lei de Mercado de Capitais.

A autarquia era (e permanece) vinculada ao Ministério da Fazenda (atual Ministério da Economia), sendo dotada de personalidade jurídica e orçamento próprios, bem como autonomia administrativa e financeira. Desde sua origem é composta de quatro diretores e um presidente, nomeados pelo Presidente da República (Art. 6º).

O local escolhido para sediar a CVM foi o Rio de Janeiro, muito provavelmente pelo peso da carga histórica da cidade como centro financeiro do

2 Disponível em < $\underline{\text { https://www1.folha.uol.com.br/mercado/2018/08/primeiro-presidente-da-cvm- }}$ descreve-evolucao-do-mercado.shtml>. Acesso em 12.06.2019 
Brasil, que abrigava também a bolsa de valores mais importante do país - a Bolsa de Valores do Rio de Janeiro (BVRJ).

As atribuições então delegadas ao Bacen pela Lei de Mercado de Capitais foram redistribuídas à nova autarquia, de forma que o Bacen continuou responsável apenas pelos títulos de dívida pública e títulos emitidos por instituições financeiras - exceção feita aos debêntures, por serem títulos de dívida de empresas privadas.

Conforme dispõe o Art. $9^{\circ}$ da Lei, à CVM caberia fiscalizar as empresas listadas nas bolsas de valores, podendo, para tanto examinar documentos contábeis de: pessoas físicas e jurídicas integrantes do mercado financeiro; companhias abertas, de fundos e sociedades de investimento; e auditores fiscais, analistas e consultores. A autarquia é competente, ainda, para requisitar documentação ou informação complementar a qualquer órgão público, e intimar pessoas para prestar informações.

Em linha com a necessidade de perseguir a transparência nas relações do mercado financeiro defendida pelo Ministro da Fazenda, a lei também concedeu à autarquia a prerrogativa de determinar a publicação de documentos ou informações pelas companhias. O dever de informação também foi replicado no Art. 19, através da criação de um sistema de registros que permitiria a disponibilização de informação das companhias ao público investidor em geral.

Ademais, a fim de valer a competência da CVM para apurar e punir condutas fraudulentas e irregulares, foram previstas sanções diversas a serem aplicadas de acordo com a gravidade da infração apurada: advertência, multa a ser calculada segundo as ORTNs, suspenção de carteira de gestão, inabilitação e até mesmo cassação de registros.

Pecava a Lei, todavia, ao arrolar bens que poderiam ser considerados valores mobiliários, sem buscar uma definição teórica que abrangesse uma categorização mais ampla. Como é sabido, ao listar os bens compreendidos pela significância de "valores mobiliários", a lei tendia à obsolescência, uma vez que 
é impossível esgotar os valores mobiliários que futuramente viriam a ser objeto da fiscalização da CVM.

O mesmo havia ocorrido na década de 1930 nos Estados Unidos da América, quando da fundação da comissão de valores mobiliários de lá, a Securities and Exchange Comission (SEC). Foram diversas as tentativas de criar um rol taxativo que abarcasse todos os tipos de securities. Enfim, a Suprema Corte dos EUA decidiu pela definição que passou a ser conhecida como Howey Definiton, por ter sido proferida no âmbito da análise de um contrato de investimento celebrado por investidores com a Howey Company. Segundo essa definição, securities seriam "um contrato de investimento em um empreendimento comum, no qual a expectativa de lucros depende unicamente dos esforços de terceiros" (EIZIRIK et al., 2008, p.32).

Felizmente, no Brasil, após algumas outras tentativas de ampliar o rol de valores mobiliários - como a Resolução $n^{0} 1.723 / 1990$ e o Decreto-Lei $n^{\circ}$ 2.286/1986 -, em 1998 a Medida Provisória $n^{\circ} 1.673$ trouxe uma definição conclusiva de valores mobiliários (muito semelhante à definição norteamericana):

Art. $1^{\circ}$ Constituem valores mobiliários, sujeitos ao regime da Lei no 6.385 , de 7 de dezembro de 1976, quando ofertados publicamente, os títulos ou contratos de investimento coletivo, que gerem direito de participação, de parceria ou de remuneração, inclusive resultante de prestação de serviços, cujos rendimentos advêm do esforço do empreendedor ou de terceiros. 


\subsection{ASSOCIAÇÃO BRASILEIRA DAS ENTIDADES DOS MERCADOS FINANCEIRO E DE CAPITAIS - ANBIMA}

A atividade de autorregulação do mercado financeiro é uma forma de regulação espontânea que não decorre diretamente do poder legislativo do Estado, nem por determinação legal indireta. É uma manifestação dos agentes do mercado financeiro que se organizam a fim de conceber interpretações complementares à legislação existente sobre a setor.

Todavia, como ressalta Ferraz $(2015$, p. 37$)$ não se trata de tentativa de desregular o Estado, mas de atender o dinamismo do mercado através da elaboração de normas convencionadas por seus agentes, consideradas as nuances técnicas e éticas e a regulação pertinente.

Assim, as práticas constituintes da autorregulação feita pela Associação costumam ser dotadas de caráter inovador, por possuírem seus agentes maior proximidade com as novidades do setor, especialmente no tocante às novas ideias desenvolvidas nos países pioneiros na estruturação do mercado financeiro.

Os agentes associados se reúnem em comitês para discutir comportamentos e para elaborar propostas de regramentos que constituem os Códigos de Melhores Práticas. Assim, a ANBIMA monitora os agentes e verifica se as práticas estão em conformidade com suas regras através do setor de Supervisão de Mercados. Ainda, visando fazer valer a adequação, a associação pode processar agentes em situação de irregularidade e propor punições em seus Conselhos de Autorregulação.

Neste caso, as penalidades variam entre uma simples advertência de desconformidade da associação até uma multa no valor de 100 (cem) vezes o valor da mensalidade ou mesmo o desligamento da associação à entidade (Art. 61 de seu Código de Boas Práticas para Fundos de Investimento). 
Outro papel da ANBIMA inclui o de certificação dos agentes do mercado financeiro. Esta frente abrange desde fundos de investimentos aderentes ao Código de Boas Práticas até agentes individuais através de exames que avaliam a capacidade profissional para exercer determinada atividade.

\section{LEGISLAÇÃO BRASILEIRA APLICÁVEL AOS FUNDOS DE INVESTIMENTO}

\subsection{I-CVM n 555, I-CVM n 558 e LEI DAS S.A. LEI No 6.404/1976}

Como mencionado anteriormente, a primeira tentativa de abordagem legal dos fundos de investimentos no Brasil foi feita através da Lei de Mercado de Capitais (Lei $n^{\circ}$ 4.728/1965). Todavia, o primeiro ato normativo da Comissão a se dedicar exclusivamente ao tema foi a Instrução da CVM de nº 409, de 2004. Eventualmente, a ICVM 409 veio a ser alterada pelas Instruções 411/04, 413/04, $450 / 07,456 / 07,465 / 08,512 / 11,522 / 12,524 / 12,536 / 13$ e 549/14. Ela foi revogada pela I-CVM 555/2014.

A referida instrução representou um marco regulatório da indústria de fundos de investimento no Brasil, por consolidar as alterações promovidas pelas Instruções anteriores em um só instrumento normativo. A instrução abrange os fundos denominados "não estruturados", ou seja, em linguagem clara, fundos de investimento de estrutura simplificada cujo funcionamento destoa da complexidade dos chamados fundos estruturados. Esses últimos, por sua vez, são subordinados a instruções específicas; por exemplo: i) os Fundos de Investimento em Direitos Creditórios (FIDCs) são disciplinados pela ICVM 356/2001 e I-CVM 444/2006; ii) os Fundos de Investimento Imobiliário (FII), pela ICVM 472/2008; iii) os Fundos de Investimentos em Participações, pela ICVM 579; e iv) os Fundos de Financiamento da Industria Cinematográfica Nacional (Funcine), pela ICVM 398/2003. 
A ICVM 555 oferece uma abordagem bastante completa no tocante aos fundos de investimento não estruturados, analisando aspectos como a constituição dos fundos, seus registros e atos pertinentes, as responsabilidades e atribuições dos agentes participantes nos funcionamentos dos fundos, a organização de carteiras dos fundos, as alterações estruturais do fundo, a liquidação e o encerramento.

Para fins de aplicação da ICVM 555, são considerados fundos não estruturados: I - Fundo de Curto Prazo; II - Fundo Referenciado; III - Fundo de Renda Fixa; IV - Fundo de Ações; V - Fundo Cambial; e VII - Fundo Multimercado.

Por sua vez, a ICVM 558 de 2015 veio a revogar a ICVM 306 de 1999, e reestruturar o regime de regras atinentes à administração de fundos de investimento. Conforme a Instrução, a administração compreende as atividades de funcionamento, manutenção e gestão de fundos de investimento, sendo duas as espécies de administrador: o administrador puramente fiduciário e o administrador gestor de recursos - que também guarda relação de fidúcia para com os quotistas e fundo, mas tem sua atuação especializada para a tomada de decisões de investimento. Essas duas funções serão melhor desenhadas no subcapítulo 4.1.

Nesta linha, a Instrução tratou do credenciamento dos administradores e gestores de fundos de investimento, estabelecendo critérios de avaliação de experiência profissional pelo proponente pessoa física e pessoa jurídica. Também abordou o tema de contratação de terceiros pelo administrador fiduciário, podendo delegar funções como tesouraria, custódia, agência de classificação de risco e até o serviço de gestão do fundo a um gestor credenciado e exclusivo.

Sobre este ponto em específico, vale anotar que o Art. 79, § $2^{\circ}$ da ICVM 555 prevê a obrigação de constar dos contratos de prestação de serviço do fundo cláusula que indique a responsabilidade solidária entre o administrador e o 
contratado. Apesar da letra da lei não esclarecer, neste caso a CVM já se manifestou no sentido de que esta solidariedade abrangeria apenas a responsabilidade civil dos agentes envolvidos, ou seja, o dever de indenizar; porém, sob a ótica da responsabilidade administrativa cada agente responde individualmente por seus atos. ${ }^{3}$

A Lei $n^{\circ}$ 6.404/1976 é praticamente silente no que tange aos fundos de investimentos, pois apenas no Art. $126, \S 1^{\circ}$ faz menção à representação dos cotistas pelo gestor do fundo em assembleias gerais de companhias investidas. Mesmo assim, são altamente valiosas as noções de deveres dos administradores de sociedades anônimas para a orientação das condutas das figuras equivalentes nos fundos de investimento, quais sejam, o gestor e o administrador. É o que ensina Norma Parente $(2016,257)$ :

Tanto o administrador quanto o gestor devem exercer suas funções com a diligência que se espera de um administrador probo (leal) e ativo (diligente), sendo certo que os princípios do dever de diligência aplicáveis ao administrador e ao gestor do fundo, por suas características de fidúcia, são os mesmos inerentes aos administradores de companhias.

\subsection{Código ANBIMA De Regulação E Melhores Práticas De Fundos De Investimento}

A ANBIMA, entidade já apresentada acima, possui presença significativa no âmbito da autorregulação do mercado financeiro e de capitais brasileiro, sendo a principal associação de agentes do mercado.

O crescimento da indústria de fundos de investimento no Brasil estimulou a criação de um manual com objetivos de i) interpretar a legislação brasileira

\footnotetext{
${ }^{3}$ CVM. PAS RJ-2005/9245. Voto do Diretor e Relator Marcelo Fernandez Trindade, 16.01.2007. Disponível em <http://www.cvm.gov.br/export/sites/cvm/sancionadores/sancionador/anexos/2007/RJ20164271_Co mpleto.pdf. $>$. Acesso em 16.06.2019.
} 
aplicável aos fundos e ii) fornecer orientações aos agentes envolvidos no mercado sobre as melhores práticas a serem adotadas.

Dessarte, o Código de Melhores Práticas elaborado pela ANBIMA opera de forma a complementar às principais normas emitidas pela CVM, e, apesar de não terem força de lei, apresenta fundamentos que são levados a sério e obedecidos pelas instituições financeiras signatárias. O caráter supletivo é evidenciado no P.Ú. do Art. $3^{\circ}$ do Código:

Parágrafo único - $\mathrm{O}$ presente Código não se sobrepõe à legislação e regulamentação vigentes, ainda que venham a ser editadas normas, após o início de sua vigência, que sejam contrárias às disposições ora trazidas. Caso haja contradição entre regras estabelecidas neste Código e normas legais ou regulamentares, a respectiva disposição deste Código deve ser desconsiderada, sem prejuízo das demais regras neste contidas.

Nas palavras de Eduardo Cherez Pavia (2016, p. 150):

No entanto, ao longo do tempo, como é natural, a regulação estatal passou a incorporar grande parte das regras autorreguladoras, atingindo todos os participantes do mercado. Não obstante, as normas autorreguladoras da ANBIMA são de extrema importância para a indústria de fundos, e são raras as instituições que não sejam, no mínimo, aderentes ao Código ANBIMA de Fundos.

Já o Art. $1^{\mathrm{o}}$ descreve os principais objetivos do Código, a saber, estabelecer:

A concorrência leal; II. A padronização de seus procedimentos; III. A maior qualidade e disponibilidade de informações sobre fundos de investimento, especialmente por meio do envio de dados pelas instituições participantes à ANBIMA; e IV. A elevação dos padrões fiduciários e a promoção das melhores práticas do mercado

Além disso o Código conta com capítulos específicos sobre a Gestão e Administração dos Fundos de Investimentos (Capítulos $X$ e IX, respectivamente), logo, é de grande utilidade à análise a que se propõe o presente estudo.

Nesse sentido, a adesão dos fundos de investimentos à ANBIMA (ou ao Código de Melhores Práticas) é feita de forma voluntária por meio da assinatura de termo de adesão. Todavia, a aprovação é concedida mediante a análise do cumprimento de requisitos previamente estabelecidos no site da associação. 


\section{COMPETÊNCIAS E RESPONSABILIDADES DOS GESTORES DOS FUNDOS DE INVESTIMENTO}

\subsection{Esclarecimentos acerca das funções de administrador e gestor}

Antes de abordar de fato a análise das competências e responsabilidades dos gestores dos fundos de investimento, faz-se necessário diferenciá-los da figura do administrador do fundo de investimento, uma vez que os conceitos de tais agentes pode ser objeto de confusão, especialmente pelo fato de que os verbos "gerir" e "administrar" serem, na prática, empregados como sinônimos. Porém, como é analisado mais à frente, ambos são solidariamente responsáveis por eventuais danos gerados ao cotista e ao patrimônio do fundo como um todo.

De forma clara, o administrador é a pessoa jurídica ou física apta a administrar carteira segundo critérios da CVM, sendo responsável por realizar a estrutura que compreende o fundo de investimentos e a exercer as funções inerentes à manutenção e ao funcionamento cotidiano do fundo, sem necessariamente ter participação direta sobre as atividades reais de gestão dos ativos - função que é delegada ao gestor. Para tanto, o administrador é autorizado a terceirizar atividades como tesouraria, escrituração, custódia e classificação de risco do fundo; podendo também contratar consultoria terceirizada para emitir pareceres sobre os investimentos.

Essa diferenciação é corroborada na opinião da CVM expressa no âmbito da Audiência Pública referente à edição da ICVM 558: ${ }^{4}$

O gestor de recursos tem funções muito importantes na administração de carteiras de valores mobiliários, entre as quais as de tomar decisões de investimento e, de acordo com a proposta definitiva de instrução, gerir os riscos dessas carteiras.

A função do administrador fiduciário também tem grande relevância, mas é de uma espécie diferente, cabendo a esse administrador atividades de controladoria, custódia e supervisão da higidez da gestão. $\mathrm{O}$ administrador fiduciário é, em resumo, o gatekeeper da estrutura dos fundos de investimento no Brasil.

\footnotetext{
${ }^{4}$ Audiência Pública SDM no $10 / 2014$.
} 
Em suma, o administrador fiduciário é responsável pela área de BackOffice (retaguarda) do fundo, realizando a fiscalização da gestão; cabe a ela processar todas as informações relativas aos investimentos, enviadas diariamente pelos gestores, a fim de precificar as cotas do fundo e de prestar informações eventuais que possam a vir solicitadas pela CVM.

Embora as Instruções citem por diversas vezes o administrador fiduciário como figura principal na constituição do fundo e na delegação das atividades de gestão a um agente especializado, na prática frequentemente é o inverso que acontece: gestoras independentes se organizam e buscam estruturar seus fundos escolhendo o administrador fiduciário.

O gestor, por sua vez, é a pessoa jurídica ou física credenciada pela CVM que concentra a expertise necessária para orientar a política de investimento do fundo, posicionando-se à frente das tomadas de decisão sobre a gestão dos ativos. Assim, é ele que exerce a função essencial do fundo, qual seja: realizar as negociações e as operações financeiras que julgue necessárias para que os investimentos do fundo tragam retornos superiores aos alcançados pelo benchmark preestabelecido. 
Não obstante o gestor e o administrador fiduciário serem agentes reconhecidamente distintos, os Arts. $91^{5}$ e $92^{6}$ da ICVM 555 dispõem de princípios que são norteadores comuns à conduta hígida de ambos agentes, como: a adoção de cuidado e diligência pertinentes ao homem probo; a atuação em favor dos interesses dos cotistas, observando o dever de lealdade para com eles e evitando práticas que possam ferir sua relação fiduciária; a vedação ao recebimento de vantagens ou benefícios provenientes de partes relacionadas das sociedades investidas.

\footnotetext{
5 Art. 91. O administrador e o gestor devem, conjuntamente, adotar as políticas, procedimentos e controles internos necessários para que a liquidez da carteira do fundo seja compatível com: I - os prazos previstos no regulamento para pagamento dos pedidos de resgate; e II - o cumprimento das obrigações do fundo. $\S 1^{\circ}$ As políticas, procedimentos e controles internos de que trata o caput devem levar em conta, no mínimo: I - a liquidez dos diferentes ativos financeiros do fundo; II - as obrigações do fundo, incluindo depósitos de margem esperados e outras garantias; III - os valores de resgate esperados em condições ordinárias, calculados com critérios estatísticos consistentes e verificáveis; e IV - o grau de dispersão da propriedade das cotas. $\S 2^{\circ} \mathrm{O}$ administrador deve submeter a carteira do fundo a testes de estresse periódicos com cenários que levem em consideração, no mínimo, as movimentações do passivo, a liquidez dos ativos, as obrigações e a cotização do fundo. $\S 3^{\circ}$ A periodicidade de que trata o $\S 2^{\circ}$ deste artigo deve ser adequada às características do fundo, às variações históricas dos cenários eleitos para o teste, e às condições de mercado vigentes. $\S 4^{\circ}$ Os critérios utilizados na elaboração das políticas, procedimentos e controles internos de liquidez, inclusive em cenários de estresse, devem ser consistentes e passíveis de verificação. $\S 5^{\circ}$ Caso o fundo invista em cotas de outros fundos de investimento, o administrador e o gestor, devem, em conjunto e diligentemente avaliar a liquidez do fundo investido, considerando, no mínimo: I - o volume investido; II - as regras de pagamento de resgate do fundo investido; e III - os sistemas e ferramentas de gestão de liquidez utilizados pelo administrador e gestor do fundo investido. $\S 6^{\circ}$ As disposições deste artigo não se aplicam aos fundos fechados.

${ }^{6}$ Art. 92. O administrador e o gestor, nas suas respectivas esferas de atuação, estão obrigados a adotar as seguintes normas de conduta: I - exercer suas atividades buscando sempre as melhores condições para o fundo, empregando cuidado e a diligência que todo homem ativo e probo costuma dispensar à administração de seus próprios negócios, atuando com lealdade em relação aos interesses dos cotistas e do fundo, evitando práticas que possam ferir a relação fiduciária com eles mantida, e respondendo por quaisquer infrações ou irregularidades que venham a ser cometidas sob sua administração ou gestão; II - exercer, ou diligenciar para que sejam exercidos, todos os direitos decorrentes do patrimônio e das atividades do fundo, ressalvado o que dispuser a política relativa ao exercício de direito de voto do fundo; e III - empregar, na defesa dos direitos do cotista, a diligência exigida pelas circunstâncias, praticando todos os atos necessários para assegurá-los, e adotando as medidas judiciais cabíveis $\S 1^{\circ}$ Sem prejuízo da remuneração que é devida ao administrador e ao gestor na qualidade de prestadores de serviços do fundo, o administrador e o gestor devem transferir ao fundo qualquer benefício ou vantagem que possam alcançar em decorrência de sua condição. $\S 2^{\circ}$ É vedado ao administrador, ao gestor e ao consultor o recebimento de qualquer remuneração, benefício ou vantagem, direta ou indiretamente por meio de partes relacionadas, que potencialmente prejudique a independência na tomada de decisão de investimento pelo fundo.
} 


\subsection{DEVERES DO GESTOR}

O gestor de fundo de investimento pode ser pessoa natural ou jurídica, desde que devidamente registrado como administrador de carteira de valores mobiliários perante a CVM, na categoria de gestor de recursos. Segundo o Art.

\section{3. $\S 3^{\circ}$ da ICVM 555 ,}

a gestão da carteira do fundo é a gestão profissional, conforme estabelecido no seu regulamento, dos ativos financeiros dela integrantes, desempenhada por pessoa natural ou jurídica credenciada como administradora de carteiras de valores mobiliários pela CVM, tendo poderes para: I - negociar e contratar, em nome do fundo de investimento, os ativos financeiros e os intermediários para realizar operações em nome do fundo, bem como firmar, quando for o caso, todo e qualquer contrato ou documento relativo à negociação e contratação dos ativos financeiros e dos referidos intermediários, qualquer que seja a sua natureza, representando o fundo de investimento, para todos os fins de direito, para essa finalidade; e II - exercer o direito de voto decorrente dos ativos financeiros detidos pelo fundo, realizando todas as demais ações necessárias para tal exercício, observado o disposto na política de voto do fundo.

A ICVM 558 permite a cumulação de categorias na obtenção do registro de administração de valores mobiliários, a saber: a de administrador fiduciário e a de gestor de recursos mobiliários. Mesmo assim, a referida instrução reforça a distinção dos papéis dos agentes, visto que o art. $2^{\circ}, \S 2^{\circ}$ deixa claro que a gestão de recursos é atividade exclusiva do administrador de valores mobiliários registrado nesta categoria, cabendo ao administrador fiduciário fiscalizar o funcionamento e a manutenção da carteira de valores mobiliários.

Conforme já mencionado, a escolha de um investidor por aportar seus recursos em um determinado fundo de investimentos ocorre pelos mais variados motivos; mas, em suma, busca-se delegar a um terceiro capacitado a tarefa de gerenciar tais recursos de maneira que o próprio investidor não estaria apto a realizar, seja por inexperiência ou por não poder se dedicar à atividade com exclusividade.

Além disso, a junção de capital de vários indivíduos em um só capital social administrado pelo fundo cria ambiente favorável ao surgimento de oportunidades não acessíveis ao nível de recursos detidos pelo investidor 
comum. Por outro lado, a expertise do administrador qualificado oferece uma camada de proteção aos cotistas, minorando ou mesmo excluindo eventuais prejuízos causados pelas intempéries do mercado.

Isto posto, ao aportar seus recursos em um fundo de investimento, o cotista confia no gestor do fundo para trazer retornos superiores ao que ele obteria caso investisse sozinho, dentro de uma amplitude de exposição de risco previamente informada. Logo, faz-se necessário que a relação entre o cotista e o gestor do fundo seja pautada pela confiança.

Em outras oportunidades, como nos artigos das instruções citadas, o legislador elencou comportamentos específicos a serem adotados pelo administrador de valores mobiliários. Trata-se de regras que criam expectativas objetivas e sem muito espaço para interpretações para além do alcance do texto da lei. Como exemplo, cita-se a imposição, presente no inciso III do Art. 16 da ICVM 558, de cumprimento do regulamento do fundo, incluindo uma relação de informações que obrigatoriamente devem constar desse documento e ser publicizadas e respeitadas pelo gestor. Por sua vez, nos incisos I e II do Art. 16, prevendo a inocuidade de se elaborar uma lista exaustiva de comportamentos a serem adotados em todas as circunstâncias que podem ocorrer no transcorrer da gestão de um fundo, o legislador indicou princípios que operam como padrões (standards) de expectativa de atuação do gestor para situações não previstas na lei.

Apesar de serem evidentes as diferenças entre os fundos de investimentos e as sociedades anônimas, as semelhanças no que tange à governança corporativa de ambas estruturas os aproximam em vários pontos, de forma que nos parece adequado traçar um paralelo entre os princípios que regem a atuação de administrador de companhia e os princípios que regem a atuação do gestor de fundo de investimentos. Desta forma, a Lei das S.A. e sua doutrina contribuem com a legislação da CVM sobre fundos para fornecer uma interpretação mais aprofundada sobre o tema. 
Os deveres de diligência, lealdade e informação estão expostos nos Arts. 153, 154 e 155 da Lei das S.A., tendo o legislador optado por indicar alguns comportamentos que são vedados ao administrador. Essa listagem, todavia, não é exaustiva, uma vez que os deveres compreendidos em tais artigos são muito mais abrangentes, como se explicará mais à frente. Por sua vez, o inciso I do Art. 16 da ICVM 558 indica que o administrador de carteira de valores deve observar em sua atuação os princípios da boa-fé, transparência, diligência e lealdade.

Propõe-se analisar os referidos princípios (ou deveres) à luz das interpretações concedidas pela doutrina acerca das duas normas, excluindo, por um lado, as ocasiões em que o regramento dos administradores de companhias abertas se afasta da atividade do gestão de recursos e incluindo, por outro lado, observações no tocante às especificidades que envolvem a cumprimento dos princípios na operação dos fundos de investimento. Assim, analisaremos o princípio da diligência, talvez o mais complexo, por compreender uma série de outros deveres implícitos.

O dever de diligência é princípio subjetivo, não sendo, então, possível uma definição prática que limite sua extensão. Por isso, deve ser feita uma avaliação da observância do princípio em cada caso concreto em que se questione a diligência do administrador.

O Art. 153 da Lei das S.A. remete ao conceito do homem probo ao indicar que o administrador "deve empregar o cuidado e diligência que todo homem ativo e probo costuma empregar na administração dos seus próprios negócios". Tal conceito tem origem na figura do pater familias do Direito Romano: o chefe de família que concentrava os poderes essenciais para cuidar dos interesses de sua família em várias esferas, dentre elas a esfera financeira, através da administração dos bens familiares. Em outras palavras, o artigo diz que o administrador deve gerir a companhia da mesma forma que o faria caso esta 
fosse sua própria, submetendo, na medida do possível, seus interesses pessoais ao interesse social da companhia.

Eizirik et al. (2008, p.401) ensinam que o dever de diligência do administrador tem por consequência cinco outros deveres, quais sejam: i) o de se qualificar, ii) o de bem administrar, iii) o de se informar, iv) o de investigar e v) o de vigiar. ${ }^{7}$

\subsubsection{Dever de se qualificar}

Em relação ao administrador de carteira de valores mobiliários, o dever de se qualificar é apurado objetivamente pela CVM, que expressa os requisitos imprescindíveis para a emissão do registro de administrador de valores mobiliários na categoria de gestor de recursos. Os requisitos variam do registro de gestor pessoa jurídica para pessoa natural, e estão disponíveis nos Arts. $3^{\circ} \mathrm{e}$ $4^{\circ}$ da I-CVM ${ }^{\circ} 558$.

Tecnicamente, o candidato deve: i) ser graduado em curso superior, em instituição oficialmente reconhecida; ii) ser aprovado em exame de certificação previamente licenciado pela CVM; e iii) comprovar experiência profissional de, no mínimo, sete anos em atividades diretamente relacionadas à gestão de carteiras administradas de valores mobiliários e/ou de fundos de investimento; ou comprovar notório saber e elevada qualificação em área de conhecimento relativa à gestão de carteiras de valores mobiliários.

\footnotetext{
7 Na realidade, para facilitar a verificação do cumprimento do dever de diligência, a doutrina, principalmente a partir da análise de casos e julgados de tribunais norte-americanos, tem ressaltado que ele se decompõe em cinco diferentes aspectos, a saber: o dever de se qualificar para o exercício do cargo; o dever de bem administrar; o dever de se informar; o dever de investigar; e o dever de vigiar (Eizirik, 2008, p.401).
} 
São exigidas também condições que atestem a idoneidade do proponente, como não ter sido condenado por crimes relativos à administração financeira ou não se encontrar em situação de débito perante credores em geral. ${ }^{8}$

Para a hipótese de pessoa jurídica, são feitas outras exigências pertinentes à estrutura da companhia, como ter sede no Brasil e ter em seu objeto social o exercício de administração de carteiras de valores mobiliários. O exercício da gestão do fundo propriamente dito não pode ser atribuído à pessoa jurídica. Apesar de a CVM aceitar que uma sociedade execute a gestão de mais de uma carteira de valores mobiliários, na prática se exige que, dentro da estrutura administrativa da pessoa jurídica, seja indicado um diretor estatutário (pessoa natural, devidamente registrado perante a CVM como administrador de carteira mobiliária na categoria de gestor de recursos) por carteira de valores mobiliários, a quem compete exercer tal atividade com exclusividade.

Ou seja, uma mesma gestora de recursos pode gerir diversos fundos de investimento, desde que comporte número proporcional de gestores ao número de fundos geridos (ao menos 1:1), a quem serão proibido atuar em qualquer outra entidade no mercado financeiro além dos fundos geridos.

Na hipótese de gestão compartilhada, a responsabilidade dos gestores é solidária (Art. 78, I - A, ICVM 555), a fim de assegurar a autonomia no cumprimento da política de investimentos à maneira do gestor. Assim, promovese a separação da condução da carteira de cada fundo e evita-se um eventual conflito de interesses. Todavia, na prática, não é incomum os estudos de análise

\footnotetext{
$8 \mathrm{~V}$ - não estar inabilitado ou suspenso para o exercício de cargo em instituições financeiras e demais entidades autorizadas a funcionar pela CVM, pelo Banco Central do Brasil, pela Superintendência de Seguros Privados - SUSEP ou pela Superintendência Nacional de Previdência Complementar PREVIC; VI - não haver sido condenado por crime falimentar, prevaricação, suborno, concussão, peculato, "lavagem" de dinheiro ou ocultação de bens, direitos e valores, contra a economia popular, a ordem econômica, as relações de consumo, a fé pública ou a propriedade pública, o sistema financeiro nacional, ou a pena criminal que vede, ainda que temporariamente, o acesso a cargos públicos, por decisão transitada em julgado, ressalvada a hipótese de reabilitação; VII - não estar impedido de administrar seus bens ou deles dispor em razão de decisão judicial ou administrativa; VIII - não estar incluído no cadastro de serviços de proteção ao crédito; IX - não estar incluído em relação de comitentes inadimplentes de entidade administradora de mercado organizado; $\mathrm{X}$ - não ter contra si títulos levados a protesto. (ICVM 555, Art. $4^{\circ}$ )
} 
macroeconômica de áreas centrais dos bancos múltiplos e gestoras de recursos exercer certa influência na tomada de decisão de seus gestores.

A lei também exige que seja indicado um diretor responsável pela avaliação de risco e um diretor de conformidade - a letra do artigo não deixa claro se esta responsabilidade é do gestor ou do administrador fiduciário.

\subsubsection{Dever de bem administrar e dever de se informar}

Para a adaptação do dever de bem administrar para os gestores de recursos, o gestor deve agir no sentido de atingir os objetivos fins do fundo, quais sejam, a maximização dos retornos obtidos através de seus investimentos mediante a menor exposição de risco possível, observadas a política de investimento prevista no regulamento. O gestor também deve implementar política de gestão de risco que abranja procedimentos para auferir com precisão os riscos envolvidos nas operações do fundo, estabelecendo condições e instrumentos para monitoramento de riscos relativos à liquidez dos ativos (crédito) e aos limites de concentração. Ao gestor também cabe otimizar a relação de risco e retorno, avaliando se os riscos atrelados a determinado investimento são razoáveis ou extrapolam os níveis parâmetro para esse tipo de investimento.

O dever de se informar e o de bem administrar são complementares, pois para a execução de uma boa administração é imprescindível que o gestor esteja bem informado. A discricionariedade na tomada de decisões de investimento deve ser amplamente baseada em informações que corroborem e fundamentem a escolha do gestor, rechaçando escolhas feitas exclusivamente por instinto. Esse dever é permanente, cabendo ao gestor se manter atualizado com informações pertinentes aos seus investimentos e às condições que possam afetar seus investimentos. 
Não obstante, não se requer que o gestor saiba de tudo que tenha relação com o desempenho de seu investimento, especialmente considerando a quantidade de informações disponíveis nos tempos atuais. Também não se exige que ele comprometa a lógica de momento da sua decisão em função de obter uma quantidade exaustiva de informações. Antes, é necessário que ele reúna informações suficientes para basear sua decisão, como o bom gestor médio o faria. Nesse sentido, Pedro Henrique Castello Brigagão (2014, p. 62):

É importante que se considere, a esse respeito, que uma decisão tomada de forma lenta pode sofrer graves punições por conta da atividade dinâmica do mercado. Em certos casos, pode ser menos custoso tomar uma decisão desinformada, mas rápida, do que recolher uma grande quantidade de informações e decidir sobre um determinado negócio de forma demorada.

\subsubsection{Dever de informar e dever de transparência}

O dever de transparência contido no Art. 157 da Lei das S.A. é a obrigação de o administrador tornar públicas quaisquer informações relacionadas aos seus interesses diretos ligados à companhia, entre as quais se destacam o número de ações que se possua e eventuais vantagens ou benefícios que possa vir a receber da companhia que administre ou de outras companhias que estejam no mesmo grupo econômico.

Adicionalmente, o dever de informar compreende disponibilizar as informações que podem afetar, direta ou indiretamente, os negócios da companhia e, por consequência, influenciar a decisão de investidores em geral. Entre essas informações, destacam-se as sobre investigações de corrupção ou até mesmo as de uma eventual oferta de aquisição de controle da companhia. Para Eizirik et al. (2008, p.451), o "dever de informar dos administradores corresponde ao direito subjetivo de ser informado dos acionistas em geral e dos acionistas minoritários em especial, posto que constitui instrumento indispensável à fiscalização da gestão social”. 
Essa ideia surge no conceito norte-americano de disclosure, que por sua vez tem origem no marco do Securities Act, publicado na conjuntura do período pós-Crise de 1929 (a Lei é de 1933). O Securities Act representou uma tentativa de resposta regulatória às condições de alta liberdade econômica, somadas à falta de transparência ${ }^{9}$ no mercado de capitais, o que contribuiu para o aprofundamento da Grande Crise. A ambição do legislador foi criar condições de mercado equânimes através do aprimoramento da transparência na divulgação de informações.

Nesse sentido, as companhias passariam a ser registradas perante a Securities and Exchange Comission (SEC) e estariam obrigadas a fornecer, periodicamente, informações sobre suas operações, saúde financeira, princípios de governança corporativa e outros dados pertinentes, visando a proteção dos investidores. ${ }^{10}$

O espírito do disclosure no direito norte-americano foi reforçado pelo Sarbanes-Oxley Act of 2002 (SOX), editado em reação aos diversos escândalos entre 2000 e $2002^{11}$ envolvendo a prática antiéticas de executivos de companhias norte-americanas, como: contabilidade criativa, destruição e falsificação de documentos financeiros e casos de round-trip trading. ${ }^{12}$ Dessa vez, a ideia

\footnotetext{
${ }^{9}$ Essa ideia está claramente explicitada nos objetivos do Securities Act: "An act to provide full and fair disclosure of the character of securities sold in interstate and foreign commerce and through the mails, and to prevent frauds in the sale thereof, and for other purposes." Disponível em $<$ https://legcounsel.house.gov/Comps/Securities\%20Act\%20Of\%201933.pdf $>$. Acesso em 06.06.2019. 10 (4) PERIODIC DISCLOSURES. Upon such terms and conditions as the Commission determines necessary in the public interest and for the protection of investors, the Commission by rule or regulation may require an issuer of a class of securities exempted under paragraph (2) to make available to investors and file with the Commission periodic disclosures regarding the issuer, its business operations, its financial condition, its corporate governance principles, its use of investor funds, and other appropriate matters, and also may provide for the suspension and termination of such a requirement with respect to that issuer. Securities Act

11 Para maiores informações sobre o tema, acessar $<$ https://www.forbes.com/2002/07/25/accountingtracker.html\#71805a7b57e8>. Acesso em 06.06.2019 12 Manipulação do mercado de ações por executivos através da compra e venda reiterada de ações de uma companhia na intenção de simular uma alta demanda por tais ações.
} 
central da legislação foi aprimorar a precisão e a confiabilidade das informações que estavam sendo divulgadas pelas companhias. ${ }^{13}$

No caso dos fundos de investimento, as I-CVM nos. 555 e 558 foram elaboradas em sintonia com o espírito de transparência embutido na Lei das S.A. Em ambas as instruções, predomina a preocupação do legislador (e de diversos agentes do mercado de fundo de investimentos, como evidenciado através de sugestões feitas no âmbito das audiências públicas envolvendo as instruções) em proteger o investidor de informações que possam induzi-lo a expectativas infundadas de retorno. Objetivava-se ainda facilitar seu trabalho de supervisão do investimento através do fornecimento de informações de qualidade. Vale citar a redação do parágrafo $2^{\circ}$ do Art. 11 , ICVM 558, que trata exatamente do tema: "As informações fornecidas devem ser úteis à avaliação do serviço prestado."

Dessarte, as informações divulgadas pelos fundos devem ser preparadas em linguagem serena, moderada, simples, clara, objetiva e concisa, além de serem consistentes com o regulamento e com a lâmina do fundo (ICVM 555, Art. 49, I e ICVM 558 Art. 11, II). Na hipótese de abordarem a rentabilidade do fundo, devem-se disponibilizar informações que incluam as taxas de administração e performance, bem como exibir índice de mercado compatível com os investimentos do fundo. Ademais, no documento deve constar explicitamente a máxima que muitos investidores falham em compreender: a de que rentabilidade passada não implica em rentabilidade futura. ${ }^{14}$

Por outro lado, se o administrador julgar que determinada informação pode afetar diretamente o desempenho da companhia e, por conseguinte, o

\footnotetext{
13 "An act to protect investors by improving the accuracy and reliability of corporate disclosures made pursuant to the securities laws, and for other purposes." Disponível em $<$ https://pcaobus.org/About/History/Documents/PDFs/Sarbanes_Oxley_Act_of_2002.pdf $>$. Acesso em 08.06.2019

${ }^{14} \mathrm{O}$ Art. $14, \S 4^{\circ}$, do Código de Boas Práticas da ANBIMA ainda exige que a lâmina do fundo apresente, dentre outras, a seguinte informação: "Ainda que o gestor da carteira mantenha sistema de gerenciamento de risco, não há garantia de completa eliminação da possibilidade de perdas para o fundo e para o investidor."
} 
interesse de seus acionistas, cabe a ele ou ao acionista realizar consulta junto à CVM para que a autarquia avalie o mérito e decida se a informação será divulgada. A análise da CVM também se aplica nos casos em que haja suspeita de que o administrador tenha agido com negligência ao divulgar informações sensíveis, podendo até mesmo ser responsabilizado.

\subsubsection{Dever de investigar e dever de vigiar}

O dever investigar é acionado mediante o aparecimento de indicadores ou suspeitas de um problema grave (red flag) que pode acarretar prejuízos para a carteira de valores do fundo, ou até mesmo um desenquadramento do fundo no tocante aos limites de alocação de recursos por tipo de ativo, de acordo com as imposições legais de sua categoria. Nessas hipóteses, o gestor pode delegar a responsabilidade de investigação ao seu diretor de compliance (conformidade), que, por sua vez, pode ser auxiliado por advogados ou consultores especializados, a depender do tipo de problema.

Um exemplo de indicador que merece a atenção do gestor é a apresentação recorrente de quedas abruptas das receitas nas demonstrações financeiras de companhia investida pelo fundo, exigindo que o gestor reavalie o investimento feito nessa empresa e, eventualmente, busque uma alternativa de saída, visando mitigar prejuízos.

A gestão do fundo se compõe de diferentes profissionais que formam equipes distintas, de acordo com suas respectivas especialidades. Frequentemente podem existir equipes de análise econômica doméstica e global, de traders e de análise voltada especificamente para companhias ou outros ativos, por exemplo. O gestor, então, figura como líder e a ele cabe coordenar as equipes na realização das ordens de investimentos segundo seu melhor entendimento. Assim, o gestor é o responsável por vigiar a afinação de seus funcionários com o seus próprios entendimentos, a fim de atingir o objetivo do 
fundo. Porém, deve fazê-lo sem incorrer no risco de "microgerir" (micromanage) as ações de seus funcionários. Como leciona Parente (2005, p. 89) "Dessa forma, via de regra, não se exige dos administradores a supervisão de cada uma das atividades desenvolvidas pelas companhias, mas o acompanhamento geral dos negócios sociais."

\subsubsection{Dever de lealdade}

O dever de lealdade tem como pedra fundamental a noção de que o gestor deve pautar suas decisões sempre em favor do interesse social do fundo, em detrimento de seus interesses pessoais. Ademais, a relação fiduciária entre cotista e gestor forma-se na expectativa de que o gestor evite possíveis situações em que possa ocorrer conflito de interesses; caso essas ocorram, deve-se selecionar a opção que esteja em melhor acordo com os objetivos do fundo de investimento.

$\mathrm{Na}$ Lei das S.A., o legislador decidiu por exemplificar o dever de lealdade através da descrição de certas condutas consideradas proibidas por ferir esse dever. No caso das ICVM $555^{15}$ e $558,{ }^{16}$ o legislador expôs uma lista, não

\footnotetext{
${ }^{15}$ Art. 89. É vedado ao administrador e ao gestor, no que aplicável, praticar os seguintes atos em nome do fundo: I - receber depósito em conta corrente; II - contrair ou efetuar empréstimos, salvo em modalidade autorizada pela CVM; III - prestar fiança, aval, aceite ou coobrigar-se sob qualquer outra forma, ressalvada a hipótese prevista no art. 125, inciso V; IV - vender cotas à prestação, sem prejuízo da integralização a prazo de cotas subscritas; V - prometer rendimento predeterminado aos cotistas; VI - realizar operações com ações fora de mercado organizado, ressalvadas as hipóteses de distribuições públicas, de exercício de direito de preferência e de conversão de debêntures em ações, exercício de bônus de subscrição, negociação de ações vinculadas a acordo de acionistas e nos casos em que a CVM tenha concedido prévia e expressa autorização; VII - utilizar recursos do fundo para pagamento de seguro contra perdas financeiras de cotistas; e VIII - praticar qualquer ato de liberalidade. Parágrafo único. Os fundos de investimento podem utilizar seus ativos para prestação de garantias de operações próprias, bem como emprestar e tomar ativos financeiros em empréstimo, desde que tais operações de empréstimo sejam cursadas exclusivamente por meio de serviço autorizado pelo Banco Central do Brasil ou pela CVM.

${ }^{16}$ Art. 17. É vedado ao administrador de carteiras de valores mobiliários: I - atuar como contraparte, direta ou indiretamente, em negócios com carteiras que administre, exceto nos seguintes casos: a) quando se tratar de administração de carteiras administradas de valores mobiliários e houver autorização, prévia e por escrito, do cliente; ou b) quando, embora formalmente contratado, não detenha, comprovadamente, poder discricionário sobre a carteira e não tenha conhecimento prévio da operação; II - modificar as características básicas dos serviços que presta sem a prévia formalização adequada nos termos previstos
} 
exaustiva, de algumas condutas vedadas ao gestor, a quem cabe ponderar suas decisões em cada caso concreto. Vale ressaltar, porém, a orientação contida no inciso VIII do Art. 17 da ICVM 558: "é vedado ao administrador negligenciar, em qualquer circunstância, a defesa dos direitos e interesses do cliente (cotista do fundo de investimentos)."

No mesmo sentido, no parágrafo único do Art. $6^{\mathrm{ol}}$ do Código de Melhores Práticas para Fundos de Investimento, encontra-se o seguinte texto: “Entende-se por relação fiduciária a relação de confiança e lealdade que se estabelece entre os cotistas dos fundos de investimento e a instituição participante, no momento em que é confiada à mesma a prestação de serviço para a qual foi contratada."

No mesmo sentido vai a decisão do diretor da CVM, Pablo Renteria, no âmbito de Processo Administrativo Sancionador RJ 2015/12087, em que se julgava a quebra de dever de lealdade por pessoa jurídica gestora de fundo:

no contrato e na regulação; III - fazer propaganda garantindo níveis de rentabilidade, com base em desempenho histórico da carteira ou de valores mobiliários e índices do mercado de valores mobiliários; IV - fazer quaisquer promessas quanto a retornos futuros da carteira; V - contrair ou efetuar empréstimos em nome dos seus clientes, salvo pelas hipóteses descritas no $\S 3^{\mathrm{o}}$; VI - prestar fiança, aval, aceite ou coobrigar-se sob qualquer outra forma em relação aos ativos administrados; VII - negociar com os valores mobiliários das carteiras que administre com a finalidade de gerar receitas de corretagem ou de rebate para si ou para terceiros; e VIII - negligenciar, em qualquer circunstância, a defesa dos direitos e interesses do cliente (...)

${ }^{17} \mathrm{O}$ artigo traz na íntegra os princípios gerais que devem reger os fundos signatários do Código ANBIMA: Art. $6^{\circ}$ - As instituições participantes devem observar, na esfera de suas atribuições e responsabilidades em relação aos fundos de investimento, as seguintes regras de regulamentação e melhores práticas: I. Desempenhar suas atribuições buscando atender aos objetivos descritos nos documentos do fundo de investimento, observada a regulamentação aplicável a cada tipo de fundo, bem como a promoção e divulgação de informações a eles relacionadas, inclusive no que diz respeito à remuneração por seus serviços, visando sempre ao fácil e correto entendimento por parte dos investidores; II. Cumprir todas as suas obrigações, devendo empregar, no exercício de sua atividade, o cuidado que toda pessoa prudente e diligente costuma dispensar à administração de seus próprios negócios, respondendo por quaisquer infrações ou irregularidades que venham a ser cometidas durante o período em que prestarem algum dos serviços previstos no $\S 1^{\circ}$ do artigo $2^{\circ}$ deste Código; III. Evitar práticas que possam ferir a relação fiduciária mantida com os cotistas dos fundos de investimento; e IV. Evitar práticas que possam vir a prejudicar a indústria de fundos de investimento e seus participantes, especialmente no que tange aos deveres e direitos relacionados às atribuições específicas de cada uma das instituições participantes, estabelecidas em contratos, regulamentos e na legislação vigente. Parágrafo único - Entende-se por relação fiduciária a relação de confiança e lealdade que se estabelece entre os cotistas dos fundos de investimento e a instituição participante, no momento em que é confiada à mesma a prestação de serviço para a qual foi contratada. 
O dever de lealdade, por seu turno, deriva da obrigação do exercício das funções valendo-se da boa-fé, tendo em vista os interesses do fundo e dos reais titulares do patrimônio, ou seja, os cotistas. Portanto, para que haja descumprimento do dever de lealdade, é necessário que o gestor ou administrador tenha praticado atos voltados a seus próprios interesses ou de terceiros em detrimento dos interesses do próprio Fundo.

\subsection{Os deveres de diligência e de lealdade e o modelo norte-americano do business judgement rule}

A chamada business judgement rule é uma regra de comportamento do administrador desenvolvida ao longo dos anos através de variadas jurisprudências de tribunais de estados norte-americanos que foram sendo aprimoradas até culminarem no modelo aplicado pela Suprema Corte de Delaware, pequeno estado localizado no nordeste dos EUA, célebre por seus tribunais e legislação especializados em temas de direito empresarial.

Como se verá com mais profundidade adiante, a ideia central da business judgement rule é que o administrador é a pessoa mais bem qualificada para conduzir os negócios da sua companhia (no caso, do fundo de investimento). Portanto, sua liberdade de decisão deve ser resguardada, através do estabelecimento de standards básicos de conduta, os quais impedem a sua responsabilização por eventuais resultados negativos de suas escolhas.

Em termos gerais, a regra consolida os deveres analisados previamente, determinando que caso, o processo de tomada de decisão do administrador tenha sido bem informado, regido pela boa-fé e pelo melhor interesse da companhia ("duty of loyalty"), e havendo o administrador realizado o seu dever de diligência ("duty of care"), ele não pode ser responsabilizado. Nas palavras de Parente (2005, p. 95):

A "business judgment rule" estabelece a presunção de que, ao decidirem a respeito da realização de determinado negócio, os administradores da companhia agiram, com conhecimento e informações adequados, com boa-fé, acreditando que as suas decisões foram tomadas de maneira a melhor atender aos interesses da companhia (...) 
Além das atribuições já mencionadas, consoantes aos Arts. 92 e 93 da ICVM 555, também é digno de menção o esforço da ANBIMA de relacionar diversas responsabilidades (atribuições) da gestora de fundo de investimentos, dentre elas as responsabilidades i) de gerenciar a liquidez da carteira de investimento do fundo conforme as diretrizes elaboradas para cada tipo de fundo, e ii) de garantir que as operações sejam compatíveis com os propósitos econômicos da política de investimento. ${ }^{18}$

\subsection{0 regulamento do fundo e a política de investimentos}

O Regulamento é o principal documento do fundo, uma vez que serve de norte para que a atuação da atividade de gestão do fundo alcance seu objetivo final: trazer lucro aos seus cotistas. Outrossim, o fundo estabelece critérios que permitem uma supervisão objetiva da atividade de gestão pelos administradores e facilitam a avaliação de uma eventual responsabilização do gestor por ações desconformes.

A maioria das informações relativas ao fundo - como nome da gestora e da administradora, benchmark, performances passadas, prazos em geral-já está presente na lâmina; mesmo assim, o regulamento do fundo de investimento

\footnotetext{
${ }^{18}$ Art. 28 - A gestão compreende o conjunto de decisões que, executadas com observância dos termos do regulamento, prospecto, ou do formulário, conforme aplicável, determinam a performance do fundo de investimento. $\S 1^{\circ}$. A gestão dos fundos de investimento deve ser exercida por gestor que esteja devidamente autorizado pela CVM para o exercício da atividade de administração de carteira de valores mobiliários. $\S 2^{\circ}$. Os profissionais da área de gestão que possuem alçada de decisão sobre as aplicações dos recursos dos fundos de investimento devem estar devidamente certificados, nos termos do Código ANBIMA de Regulação e Melhores Práticas para o Programa de Certificação Continuada. $\S 3^{\circ}$. A instituição participante gestora do fundo de investimento é responsável: I. Pelas decisões de investimento e desinvestimento, segundo a política de investimento estabelecida nos documentos de cada fundo, conforme aplicável; II. Pelas respectivas ordens de compra e venda de ativos financeiros e demais modalidades operacionais, incluindo direitos creditórios; III. Pelo envio das informações relativas a negócios realizados pelo fundo de investimento ao administrador do fundo ou ao prestador de serviço contratado para tal; IV. Pelo gerenciamento da liquidez das carteiras dos fundos de investimento, de acordo com as diretrizes elaboradas pelo Conselho de Regulação e Melhores Práticas para cada tipo de fundo regulado por este Código; e $20 \mathrm{~V}$. Por garantir que as operações realizadas pelo fundo de investimento tenham sempre propósitos econômicos compatíveis com sua política de investimento, sobretudo aquelas referentes a empréstimos de títulos e valores mobiliários.
} 
abrange esses dados e tantas outros de forma mais aprofundada. $\mathrm{O}$ documento em muito se assemelha ao estatuto social das companhias, visando i) oferecer ao eventual investidor todas as informações dos agentes envolvidos no funcionamento do fundo e ii) estabelecer regras claras sobre aspectos como prazos para entrada e resgate de cotas, taxas de administração e performance a serem cobradas, política de investimentos do fundo e identificação de fatores de risco. Tais fatores são essenciais para que o investidor decida pelo aporte de seus recursos no fundo de investimento.

O fator de clareza também é motivo de atenção por parte da ANBIMA, ao redigir o Art. 32 de seu Código de Boas Práticas: "O regulamento de um fundo de investimento deve ser claro e objetivo quanto à política de investimentos, incluindo as faixas de alocação de ativos, limites de concentração e a maneira pela qual se dá o processo de análise e seleção dos mesmos (...)".

Para a presente análise, interessa em especial esmiuçar a política de investimento dos fundos e seus fatores de risco, uma vez que o desvio desses padrões pode servir para motivar uma eventual responsabilização do gestor do fundo, em caso de prejuízos aos cotistas ou até mesmo por exposição a riscos imprevistos. Nesse sentido, o Art. 44 da ICVM 558 disciplina as informações básicas que devem constar do regulamento do fundo no tocante a sua política de investimentos:

I - o percentual máximo de aplicação em ativos financeiros de emissão do administrador, gestor ou de empresa a eles ligada, observado o disposto no art. 102 desta Instrução;

II - o percentual máximo de aplicação em cotas de fundos de investimento administrados pelo administrador, gestor ou por empresa a eles ligada;

III - o percentual máximo de aplicação em ativos financeiros de um mesmo emissor, observados os limites do art. 102 desta Instrução; e

IV - a possibilidade, se for o caso, de o fundo realizar operações em valor superior ao seu patrimônio, com a indicação de seus níveis de alavancagem, observados os conceitos do item 3 da lâmina.

Assim, parece que o legislador buscou, nos incisos I e II, esclarecer ao cotista o grau de relacionamento da política de gestão do fundo quanto aos ativos 
de sua própria emissão, facilitando a identificação de possível conflito de interesse na alocação de recursos do fundo em produtos que possam trazer benefícios financeiros de forma indireta a esses agentes através de rebates, por exemplo.

No inciso IV indica-se a obrigação de se informar o nível de alavancagem do fundo, que permite ao investidor avaliar se o perfil de risco do fundo encontra-se adequado às suas pretensões. Além disso, o nível de alavancagem do fundo é de extrema importância, uma vez que um fundo alavancado pode ter prejuízos além de seu capital social integralizado, gerando obrigação aos cotistas de realizar novos aportes a fim de cobrir os valores das dívidas, ${ }^{19}$ conforme determina o Art. 15 da ICVM 555. ${ }^{20}$ Por outro lado, o nível de alavancagem também serve de critério para responsabilização de gestores pelos prejuízos causados, caso desrespeitem os limites estabelecidos no regulamento.

Ademais, o legislador se preocupou em tornar factível a apuração de que a gestão do fundo esteja em conformidade com as políticas estabelecidas no regulamento; cf. Art. 91, $\S 4^{\circ}$, da ICVM 558: “Os critérios utilizados na elaboração das políticas, procedimentos e controles internos de liquidez, inclusive em cenários de estresse, devem ser consistentes e passíveis de verificação."

A política de investimentos aborda os critérios de alocação e limites de concentração de recursos da carteira do fundo, permitindo uma percepção da filosofia de investimento dos fundos. Como exemplo, segue um trecho da política de investimentos do Fundo Dynamo Cougar FIA, um dos mais antigos do Brasil:

Art. $3^{\circ} \mathrm{O}$ objetivo do FUNDO é proporcionar a seus participantes valorização real a médio e longo prazo de suas quotas, mediante aplicação de recursos em carteira

\footnotetext{
${ }^{19}$ Para mais informações, verificar o caso dos fundos da gestora de recursos GWI Private. Disponível em $\quad<$ https://veja.abril.com.br/economia/gwi-convoca-cotistas-a-fazer-novos-aportes-em-fundo/>. Acesso em 10.06.2019.

${ }^{20}$ Art. 15. Os cotistas respondem por eventual patrimônio líquido negativo do fundo, sem prejuízo da responsabilidade do administrador e do gestor em caso de inobservância da política de investimento ou dos limites de concentração previstos no regulamento e nesta Instrução.
} 
diversificada de ativos financeiros, tendo como principal fator de risco a variação de preço de ações admitidas à negociação no mercado organizado, observadas as regulamentações legais e regulamentares em vigor. O FUNDO adota como filosofia de investimento na gestão de ações uma análise exclusivamente fundamentalista, visando, através de uma postura ativa junto às companhias, retornos consistentes a médio e longo prazo, com menor preocupação com liquidez com a liquidez imediata. ${ }^{21}$

Parágrafo Único: Tendo em vista a política de investimentos acima descrita, o FUNDO se caracteriza como um fundo de ações, nos termos da regulamentação em vigor.

\section{RESPONSABILIZAÇÃO DO GESTOR DO FUNDO DE INVESTIMENTOS}

\subsection{Noções introdutórias à responsabilidade civil no direito brasileiro}

A responsabilidade civil busca indenizar determinada pessoa, física ou jurídica, por prejuízo financeiramente calculável gerado por ato de terceiro. A ideia ocorre da necessidade de um agente responder pelas consequências dos seus atos, buscando reestabelecer o estado em que a pessoa prejudicada se encontrava no momento anterior à ocorrência do ato que a lesou (o status quo ante). Como ensina Lopes (1962, p. 187), “a responsabilidade é a obrigação de apurar um dano, seja por decorrer de uma culpa ou de uma outra circunstância legal que a justifique, como a culpa presumida, ou por ser uma circunstância meramente objetiva".

$\mathrm{O}$ ato que dá origem à responsabilização civil pode ser de duas espécies: i) de obrigação contratual, ${ }^{22}$ proveniente do descumprimento ou de cláusulas contratuais ou, genericamente, de uma obrigação preexistente, como nem sempre é possível aferir a existência de um contrato escrito; e ii) extracontratual (ou aquiliana), que abrange fatos decorrentes do comportamento humano em geral, que estejam em desacordo com direito positivado ou em relação a um

\footnotetext{
${ }^{21}$ Disponível em $<$ http://cvmweb.cvm.gov.br/swb/default.asp?sg sistema=fundosreg $>$. Acesso em 07.06.2019

22 Art. 389 e seg. do Código Civil. Art. 422 do Código Civil: Os contratantes são obrigados a guardar, assim na conclusão do contrato, como em sua execução, os princípios de probidade e boa-fé."
} 
padrão de comportamento esperado de um agente. $\mathrm{Na}$ análise da responsabilidade civil, o princípio da boa-fé objetiva é diretamente relacionado com o dever de diligência do agente.

Uma leitura atenta dessa conceituação permite inferir as duas principais teorias de responsabilidade presentes no ordenamento jurídico brasileiro: i) a teoria da responsabilidade subjetiva, considerada como regra de aplicação geral, que requer que seja apurada a culpa do agente para que a sua responsabilidade seja procedente; e ii) a teoria da responsabilidade objetiva, que se efetiva de modo excepcional, apenas exigindo a comprovação de nexo causal para que o agente causador do dano seja obrigado a repará-lo.

A responsabilidade objetiva não se presume, surge de texto de lei que a implique para determinada atividade, seja por envolver risco significativo ou por configurar relação de consumo, merecendo amparo ao consumidor na sua condição de hipossuficiente. Nas palavras de Silvio de Salvo Venosa: "Leva-se em conta o perigo da atividade do causador do dano por sua natureza e pela natureza dos meios adotados."

A responsabilidade subjetiva está presente no Art. $186^{23}$ do Código Civil, enquanto a previsão da responsabilidade objetiva é consagrada no parágrafo único do Art. $927^{24}$.

O ato que dá origem à responsabilização pode ser de duas espécies: i) de obrigação contratual, ${ }^{25}$ proveniente justamente do descumprimento ou de cláusulas contratuais ou, genericamente, de uma obrigação preexistente, como nem sempre é possível aferir a existência de um contrato escrito; e ii)

\footnotetext{
${ }^{23}$ Art. 186. Aquele que, por ação ou omissão voluntária, negligência ou imprudência, violar direito e causar dano a outrem, ainda que exclusivamente moral, comete ato ilícito.

${ }^{24}$ Art. 927. Aquele que, por ato ilícito (arts. 186 e 187), causar dano a outrem, fica obrigado a repará-lo. Parágrafo único. Haverá obrigação de reparar o dano, independentemente de culpa, nos casos especificados em lei, ou quando a atividade normalmente desenvolvida pelo autor do dano implicar, por sua natureza, risco para os direitos de outrem.

${ }^{25}$ Art. 389 e segs. do Código Civil.
} 
extracontratual (ou aquiliana) decorrente da necessidade de um agente responder pelas consequências dos seus atos.

Há ainda as espécies de responsabilidade solidária e subsidiária; como se vê à frente, essa distinção é importante para compreender a relação existente entre o gestor de recursos e o administrador fiduciário.

O fundamento dessa solidariedade legal advém do fato de que, ontologicamente, não cabe indagar da materialidade da participação de cada um, nem o resultado danoso comporta uma análise das contribuições individuais

Para compreender a aplicação da responsabilidade subjetiva, é necessário primeiramente entender o conceito de culpa: a falta em dever cometida por um agente, por dolo, imperícia, negligência ou imprudência, que gera um prejuízo a uma terceira pessoa. Os três últimos aspectos (imperícia, negligência e imprudência) são manifestações opostas do dever de diligência.

A imperícia corresponde à execução de uma ação sem os conhecimentos necessários para o fazê-lo. Pode-se citar como exemplo o caso de gestor que se arvora em operações de risco sem ter a experiência e o conhecimento necessários para obter êxito; por exemplo, um gestor de ativos de renda fixa que decide operar mercados de opções futuras de açúcar. ${ }^{26}$

A negligência é a ignorância deliberada do agente sobre determinada condição que afeta negativamente o ato a ser executado, causando prejuízo. Seria o caso do gestor que, sabendo da existência de condições adversas com alto grau de probabilidade de prejuízo, decide por adquirir um ativo a troco de interesses pessoais.

A imprudência ocorre quando o agente, sendo apto a executar uma ação, o faz sem o devido zelo, ignorando os deveres E cuidados inerentes ao ato. Um

\footnotetext{
${ }^{26}$ Casos reais podem ser encontrados nas operações de hedge através de deritativos realizadas pelos administradores da Sadia e Aracruz Celulose. Disponíveis em: $<$ http://www.cvm.gov.br/export/sites/cvm/decisoes/anexos/2015/20150519/9650.pdf>, $<$ http://www.cvm.gov.br/export/sites/cvm/sancionadores/sancionador/anexos/2010/20101214_PAS_18 08.pdf>. Acessos em 09.06.2019.
} 
exemplo é o do gestor do fundo que decide realizar um investimento sem ter cumprido de forma satisfatória o seu dever de se informar, tomando uma decisão instintiva. A concretização da responsabilidade subjetiva ocorre mediante o reconhecimento da culpa do agente que causou o dano a outrem por ter deixado de cumprir seu dever. Já a responsabilidade objetiva se fundamenta na teoria de risco da atividade realizada, que se traduz na dispensabilidade da culpa do agente.

A teoria do risco, por sua vez, possui diferentes vertentes. Ocorre o risco da atividade quando um agente, via de regra pessoa jurídica, decide empregar seu capital no desenvolvimento de atividade empresarial dotada de risco extraordinário por natureza, ${ }^{27}$ de forma que a empresa passa a assumir riscos relacionados às atividades por ela desempenhada. Essa teoria possui interpretação mais ampliada, sob o nome de risco-proveito, sendo baseada na "ideia de que o dano deve ser reparado por aquele que retira algum proveito ou vantagem de fato lesivo". ${ }^{28}$

Há também o risco-profissional, segundo o qual o empregador responde pelos riscos a que expõe seus empregados na execução dos serviços a que os encarrega, e também pelos danos gerados por seus empregados a terceiros. $\mathrm{O}$ Código de Defesa do Consumidor traz, ainda, as responsabilidades por fato de produto ou serviço e a teoria do risco do empreendimento.

Todavia, não se encontra no Código Civil nenhuma tese acerca da responsabilidade dos administradores de pessoas jurídicas em geral. Assim, parte-se para a análise da Lei das S.A., das Instruções da CVM e as respectivas jurisprudências proferidas sobre o tema.

\subsubsection{Tipos de obrigação: obrigação de meio x obrigação de fim}

\footnotetext{
27 Art. 927, Codigo Civil FORMATO ARTIGO DE LEI DISPONIBILIZADA EM SITE DA INTERNET

${ }^{28}$ Rui Stocco - Cap. I p. 189 citando Sergio Cavalieri Filho (Comentários ao novo Código Civil. Coord. Sálvio de Figueiredo Teixer. 2ed. Rio de Janeiro. Forense, 2007, p.12-13). FORMATO LIVRO
} 
A teoria geral de obrigação se organiza em torno da relação entre, ao menos, dois agentes - o credor e o devedor (ou o prestador de serviço) - que acordam, a priori voluntariamente, a realização de uma prestação contratada pelo credor enquanto o devedor, via de regra, é remunerado de alguma forma em contrapartida.

Dentro das espécies de organização das obrigações, existe aquela que as divide em dois tipos: obrigações de meio e obrigações de fim.

$\mathrm{Na}$ obrigação de meio, o sujeito passivo se obriga a realizar certa atividade empregando o seus melhores esforços para obter êxito ao fim; ocorre, justamente, por ser da área da prestação a imprevisibilidade do resultado, sendo impossível garantir certeza no seu sucesso. Aqui surge novamente o pater familias, conceito do Direito Romano segundo o qual se deve ter diligência em conduzir suas ações durante a realização da obrigação, assim como as conduziria caso fosse em seu benefício próprio, ou, para se ater ao conceito original, assim como se realizasse a prestação em prol de sua família. Esse tipo de obrigação abrange as relações profissionais de médicos, advogados e administradores, como se explica adiante.

O oposto é a relação obrigacional de fim, segundo a qual o devedor é contratado para realizar prestação que permite aferir de forma precisa o cumprimento do objeto, sendo a sua prestação previsível e independente de fatores externos ao negócio jurídico. Por consequência, a imputação de responsabilidade por essa espécie de obrigação desconsidera a culpa do devedor na hipótese de falta, exceções feitas às teorias de caso fortuito e força maior e da imprevisão. Exemplo lógico desse tipo de obrigação é o descumprimento de cláusula de objeto de contrato.

A grande parte da doutrina, parece que o dever de diligência exigido na obrigação do administrador de companhia, bem como o do gestor de fundo de 
investimentos, configura obrigação de meio, e não de fim. Nas palavras de Nelson Eizirik et al. (2008, p.403):

Isto porque o dever de diligência constitui uma obrigação de meio e não uma obrigação de resultado. O conteúdo da prestação nas obrigações de meio consiste justamente no comportamento diligente do devedor em benefício do credor, não sendo necessário que o resultado seja alcançado.

Já Eduardo Cherez Pavia (2016, p.166) diz:

Nesse sentido, é importante ressaltar que a obrigação do administrador, e do gestor, quando contratado, é de meio, e não de resultado: não há promessa do sucesso financeiro do investimento. Há, pelo contrário, vedação expressa, tanto da CVM como pela ANBIMA, de que tal promessa de rentabilidade venha se concretizar.

\section{E Luiz Antonio de Sampaio Campos afirma:}

Outra peculiaridade do sistema de responsabilização dos administradores é o fato de que, para sua apuração, não se deve realizar juízo a respeito do mérito, conteúdo ou do acerto da decisão ou do ato praticado pelo administrador. O juízo deve ser de procedimento, ressalvada a hipótese de conflito de interesses, em que se permite maior análise do mérito da decisão.

Por fim, Modesto Carvalhosa (2016, p. 876): “(...) deve ser ressaltado que a esse padrão de conduta diligente corresponde uma obrigação de meio e não de resultado".

Vale mencionar que na teoria originária do direito societário predominava a visão contratualista da sociedade, segunda a qual o interesse da companhia deveria coincidir com o interesse dos acionistas positivado no estatuto social da mesmo, sendo esse hierarquicamente superior ao interesse social. Dentro desse ponto de vista, o administrador figurava como um funcionário da empresa, sendo submisso aos interesses dos acionistas.

Com o passar do tempo, a evolução da economia trouxe consigo novas discussões sobre o tema, surgindo regulações mais sofisticadas e uma nova concepção de companhia. A teoria moderna predominante enxerga na companhia mais que um veículo de expressão da vontade "contratualizada" dos acionistas, inserindo a companhia na sociedade através de uma visão multidisciplinar de seus objetivos. Aqui, a companhia se torna uma instituição 
dotada de interesses próprios, com autonomia, na medida que busca compatibilizar interesses internos com interesses externos da sociedade e da saúde do mercado financeiro como um todo.

É nesse contexto que os administradores passam a orientar os interesses sociais da companhia em observância ao arcabouço normativo existente. Daí emana a interpretação de que o vínculo obrigacional e, por conseguinte, de responsabilidade entre a companhia e seus administradores decorre das leis existentes e não apenas de seu estatuto social. É nesse sentido que Eizirik (2009, p. 393) afirma que o descumprimento dos deveres por partes dos administradores não importa em inadimplemento contratual, constituindo, portanto delitos $e x$ lege. Também pensam assim Carvalhosa e Kuyven (2016, p. 841): (os administradores) "não tem seu poder-dever derivado da vontade da companhia, mas da Lei, a qual pode ser complementada pelo estatuto social e pelos usos e costumes (boa-fé objetiva)".

Guardadas as devidas diferenças, é no mesmo sentido que se insere a figura do gestor do fundo de investimento, com obrigações e deveres previstos em lei.

\subsection{Responsabilidade do Gestor - ICVM 555, ICVM 558 e Lei Das S.A.}

Parece que, à semelhança da Lei das S.A., o legislador das instruções analisadas no presente estudo optou por um sistema misto obrigações dos gestores de fundo de investimentos. Assim, em parte, reconhece-se a ineficácia de se tentar criar uma previsão legal de todos os comportamentos a serem adotados e práticas a serem vedadas na condução da gestão do fundo, empregando uma análise subjetiva de sua atuação conforme a observância dos deveres de boa-fé, diligência e lealdade. 
Não obstante, o aspecto subjetivo desses standards é harmonizado com orientações pontuais e vedações a práticas que, ao longo do tempo, se provaram recorrentes na gestão temerária dos fundos de investimento. Nesse sentido, como mencionado anteriormente, o Art. 89 da ICVM 555 e o Art. 17 da ICVM 558 trazem uma lista de práticas de gestão consideradas ilegais, ao passo que os Arts. 91 e 92 da ICVM 555 e o Art. 16 da ICVM 558 indicam deveres a serem adotados e normas de condutas a serem obedecidas pelos gestores.

Isto posto, o gestor pode ser responsabilizado por desenquadramento ativo da carteira, gestão em desconformidade com a política de investimentos ${ }^{29}$ e de riscos.

A leitura do parágrafo $3^{\circ}$ do Art.79 (ICVM 555) nos induz a entender que a responsabilidade do gestor (e do administrador fiduciário) ao agir na ilegalidade ou de forma contrária aos deveres de boa-fé, lealdade e diligência, seria do tipo objetiva, não exigindo a comprovação de culpa. Nesse sentido diz a letra do referido artigo: o administrador de fundo de investimentos responde por prejuízos decorrentes de atos e omissões próprios a que der causa, sempre que agir de forma contrária à lei, ao regulamento e aos atos normativos expedidos pela CVM.

Da mesma forma pensa Norma Parente (2018, p. 310):

Ambos têm responsabilidade objetiva, não sendo necessário comprovar a culpa. O simples descumprimento de seus deveres já é suficiente para que tanto o administrador como o gestor sejam responsabilizados por seus atos. Ambos têm o dever genérico de respeitar a integridade patrimonial e política dos investidores, de agir com boa-fé e lealdade, ou seja, de não prejudicar nem lesar o outro, conforme princípio derivado do direito romano, neminem laedere.

A partir da análise conjunta das Instruções da CVM com os artigos Lei das S.A. não é possível concluir com certeza se a responsabilidade do gestor de

\footnotetext{
${ }^{29}$ Art. 15 da I-CVM 555.
} 
fundos de investimentos é subjetiva. Assim, nos parecesse que o legislador da CVM também empregou um hibrido de responsabilidade.

As obrigações legais que determinam condutas objetivas na atuação do gestor seriam passíveis de responsabilidade objetiva. A obediência ao regulamento do fundo, e a observância das normas dispostas nos Arts. 89 e 17 da I-CVM 558, por exemplo, se descumpridas acarretam na responsabilização civil e administrativa do agente, sem a necessidade de provar a ocorrência de culpa

Em outra categoria, estariam as obrigações legais não previstas em lei, mas que decorrem do caráter subjetivo da observância dos standards de comportamento pelo gestor. Nesta hipótese, a responsabilidade também parece ser objetiva, mas permitindo o afastamento da obrigação de indenizar caso o gestor comprove que agiu em conformidade com os deveres de boa-fé, diligência e lealdade.

Todavia, esse entendimento é minoritário. O ordenamento jurídico brasileiro tende a explicitar as hipóteses de aplicação de responsabilidade objetiva - como é o caso do Código de Defesa do Consumidor -, de forma que a doutrina majoritária defende que a responsabilidade dos gestores seria subjetiva, a avaliar a culpa existente segundo os critérios dos standards de comportamento propostos nas Instruções. Nesse sentido conclui Perricone (2010, p. 100):

A análise sistemática das leis e normas que tratam a regulação e funcionamento dos fundos investimento, nos leva a concluir ser subjetiva a responsabilidade de seus administradores, quer em face dos parâmetros de indicação do elemento culpa constante nas formas expedidas pelos órgãos reguladores, quer em face da ausência, em lei e naquelas normas, de expressa designação da responsabilidade objetiva. Assim, somente depois de provada a culpa do administrador, a existência do dano e o nexo de causalidade, é que surgirá o dever de reparar os prejuízos causados aos fundos que administra. 
E também Lamy Filho ao abordar o tema sob o aspecto do administrador de companhia (1996, p. 405):

$\mathrm{O}$ administrador somente responde por prejuízos decorrentes de seus atos quando age com culpa, em sentido lato: mesmo no caso de violação da lei ou do estatuto, não há responsabilidade objetiva, mas apenas inversão do ônus da prova. Como expõe Valverde (1959, p. 329):

Dir-se-á que a lei presume, nesses casos, a culpa do diretor pelo que a ele incumbirá provar que a violação da lei ou dos estatutos resultou de circunstâncias especialíssimas, por ele não provocadas ou relativamente às quais não podia ele ter nenhuma influência, ou, ainda, que os prejuízos verificados não ocorreriam em qualquer hipótese.

\subsection{Da relação de consumo na aquisição de quotas de fundo de investimento}

O entendimento do STJ no tocante às relações de clientes com suas respectivas instituições financeiras está consolidado no enunciado da Súmula $\mathrm{n}^{\circ}$ 297, que determina a aplicação do Código de Defesa do Consumidor em relação às instituições financeiras ${ }^{30}$. Todavia, os precedentes anexados no documento integral da Súmula levam a crer que a sua aplicação tem sido pertinente na análise das relações de clientes com seus bancos na condição de prestadores de serviços, principalmente em operações feitas mediante contrato de adesão, como contratos de crédito e contratação de caderneta de poupança, à luz do Art. $3^{\circ}, \S$ $2^{\circ}$ do CDC. ${ }^{31}$ No mesmos sentido entendeu o STF ao julgar Ação Direta de Inconstitucionalidade de $n^{0} 2591$ sobre a aplicação do CDC nas relações com instituições financeiras:

\footnotetext{
${ }^{30}$ Súmula no 297 Superior Tribunal de Justiça. Brasília: Segunda Seção, 12.05.2004: O Código de Defesa do Consumidor é aplicável às instituições financeiras.

${ }^{31}$ Art. $3^{\circ}, \S 2^{\circ}$. Serviço é qualquer atividade fornecida no mercado de consumo, mediante remuneração, inclusive as de natureza bancária, financeira, de crédito e securitária, salvo as decorrentes das relações de caráter trabalhista.
} 
As instituições financeiras estão, todas elas, alcançadas pela incidência das normas veiculadas pelo Código de Defesa do Consumidor. 2. "Consumidor", para os efeitos do Código de Defesa do Consumidor, é toda pessoa física ou jurídica que utiliza, como destinatário final, atividade bancária, financeira e de crédito. 3. Ação direta julgada improcedente.

Por consequência, os precedentes da referida Súmula não apresentam nenhum julgado envolvendo investimentos com algum nível de sofisticação, como é o caso dos fundos de investimentos, limitando-se a operações básicas que almejam a preservação do poder aquisitivo dos clientes. Assim, à primeira vista, nos parecer que essa súmula não tem aplicação nas hipóteses de aquisição de quotas de fundos de investimento, justamente por configurarem espécie de investimento.

Para fins de diferenciação da figura do poupador do investidor vale citar trecho do voto da Ministra Nancy Andrighi, no âmbito do Recurso Especial Nº. 106.888-PR (96.000056344-6) $)^{32}$ :

O poupador não é investidor de mercado mobiliário, e sim consumidor de serviço de depósito, mediante remuneração por taxas médias fixadas pelo Poder Público, das quais se beneficiam as instituições financeiras, ainda que indiretamente, porque captam recursos populares que passam a constituir seu capital de giro, e desponta especial interesse dos bancos porque o valor monetário que circula é determinante, dentre outros aspectos, das reservas que devem ser mantidas nos próprios bancos.

A jurisprudência do STJ tem optado pela aplicação do CDC nos contratos com fundos de investimento. Todavia, nota-se nas decisões proferidas alguns critérios objetivos para que seja aplicado o CDC nessas relações, quais são: (i) o reconhecimento de que houve falha do gestor no que tange o fornecimento de informações concisas sobre os riscos envolvidos nas operações compreendidas pela política de investimento do fundo; ou (ii) a realização de operações em desconformidade com as informações disponibilizadas nos documentos do

\footnotetext{
${ }^{32}$ Recurso Especial No. 106.888-PR (96.000056344-6). Superior Tribunal de Justiça. Relator Ministro Cesar Asfor Rocha. Brasília, 28.03.2001.
} 
fundo, em especial no tocante à exposição deliberada a riscos imprevistos; ou (iii) qualquer comportamento caracterize indicio de gestão temerária do fundo. Nesse sentido, entendimento do Ministro Antonio Carlos Ferreira, da Quarta Turma do STJ:

\section{DIREITO DO CONSUMIDOR. INCIDÊNCIA DO CDC AOS CONTRATOS DE APLICAÇÃO FINANCEIRA EM FUNDOS DE INVESTIMENTO.}

O CDC é aplicável aos contratos referentes a aplicações em fundos de investimento firmados entre as instituições financeiras e seus clientes, pessoas físicas e destinatários finais, que contrataram o serviço da instituição financeira par investir economias amealhadas ao longo da vida. Nessa situação, é aplicável o disposto na Súmula 297 do STJ, segundo a qual "O Código de Defesa do Consumidor é aplicável às instituições financeiras". REsp 656.932-SP, Rel. Min. Antonio Carlos Ferreira, julgado em 24/4/2014. Brasília.

Dentro da jurisprudência analisada há também ação proposta por investidores qualificados em que se decidiu pela lógica de que o prejuízo decorrente de aplicações de alto risco não enseja a reparação patrimonial do quotista, justamente por ser o fator risco da natureza das operações do fundo, e pelo fato dos quotistas serem cientes dessa condição ${ }^{33}$. No caso referido, o Ministro Relator Sidnei Beneti citou interessante doutrina ${ }^{34}$ para embasar a tese

\footnotetext{
33 "No caso de aplicação em fundo de investimentos de alto risco, por investidores qualificados, experientes em aplicações financeiras, não há que se reconhecer direito a serem imunes a rendimentos significativamente menores em período de perdas gerais no setor, à invocação do dever de informar e de inversão do ônus da prova (expressamente afastada, no caso dos autos)(...)". Ementa do REsp 1214318. Brasília, Superior Tribunal de Justiça. Ministro Relator Sidnei Benetti.02.05.2012

34 "Não se configura, no caso, nenhuma das formas de vulnerabilidade do consumidor, distinguidas por CLÁUDIA LIMA MARQUES, isto é, a técnica, a jurídica e a fática ("Contratos no Código de Defesa do Consumidor”, S. Paulo, Revista dos Tribunais, $3^{\text {a }}$ ed., 199, p. 147), assim resumidos por RODRIGO ALVES DA SILVA, "Os Fundos de Investimento Financeiro à Luz do Código de Defesa do Consumidor', em "Direito Bancário e Temas Afins", org. Geraldo José Guimarães da Silva e Antonio Márcio da Cunha Guimarães, Campinas, CS Edições Ltda., 2002, p. 636): É preciso verificar que o cliente-quotista é vulnerável de forma técnica, jurídica e fática. A vulnerabilidade técnica se revela quando o investidor, sem conhecer os riscos de seus negócios, firma contrato de adesão com a instituição administradora. Os conhecimentos deficientes no campo dos investimentos, por sinal muito mal explicados ao público, remete-nos a idéia de vulnerabilidade jurídica, pois o quotista não conhece, por vezes, o alcance do conteúdo obrigacional assumido com o banco. Por fim, há vulnerabilidade
} 
de que os investidores qualificados, por serem dotados de expertise sobre o mercado financeiro e suas nuances, não poderiam invocar a vulnerabilidade que legitima o consumidor a ser amparado pelo Código de Defesa do Consumidor. Todavia, nesse caso são investidores reconhecidamente qualificados pela CVM, logo, a referida decisão não tem aplicação geral, se limitando a essa espécie de investidor.

A responsabilidade civil acolhida pelo legislador do Código de Defesa do Consumidor é do tipo objetiva, ou seja, não requer a comprovação de culpa do prestador de serviço, apenas a demonstração de prejuízo e do nexo causal. Assim, aplica-se a regra geral de inversão do ônus da prova, incumbindo ao prestador de serviços apresentar evidências que afastem a sua responsabilidade. O STJ tem consolidado entendimento nesse sentido, de que o gestor de fundo de investimento está sujeito à responsabilidade objetiva, conforme interpretação da Súmula $n^{\circ} 297$ e do Art. 14 e $3^{\circ}$ do CDC.

A problemática emana do fato de que nem todos os investidores que adquirem quotas de fundo de investimento estão em condição de vulnerabilidade. Mesmo que não classificados como qualificados pela CVM, muitos investidores (inclusive profissionais) com conhecimento sobre o mercado financeiro optam por investir em fundos, conhecendo os riscos envolvidos. Apesar das decisões citadas, a jurisprudência do STJ encontrada sobre a matéria não é extensa, de maneira que não é possível precisar qual seria o nível mínimo de expertise sobre investimentos que afastaria o fator vulnerabilidade do investidor e, por consequência, a relação de consumo.

socioeconômica, tendo em vista que as instituições de investimento, por sua posição economicamente favorável lançam mão de contratos de adesão com normas sempre voltadas à proteção da instituição, obedecendo ao regulamento do Banco Central e da CVM". Trecho da decisão monocrática do Ministro Sidnei Betti no âmbito do REsp 1214318. Brasília, Superior Tribunal de Justiça. Ministro Relator Sidnei Benetti.02.05.2012 
Nelson Eizirik (2008, p. 562) em parecer redigido sobre o tema, se manifestou contrário a incidência do CDC nas relações de investimentos em Fundos de Investimento Financeiros (uma denominação global que abrange fundos de renda fixa e renda variável). O seu entendimento é de que os serviços bancários e financeiros contidos no $\S 2$ do Art. $3^{\circ}$ do referido Código não compreendem as atividades de investimento, e que o dinheiro per se não pode ser considerado um "bem final" - como requer a teoria finalística consumerista. Em suas palavras:

Assim, quem adquire quotas de um fundo de investimento financeiro é considerado investidor - e não consumidor - do mercado de valores mobiliários, o qual é submetido à regulamentação e fiscalização da CVM, agência reguladora que dispõe de amplos poderes para proteger os investidores.

Parte da doutrina difere deste entendimento, como Eduardo Cherez Paiva (2016, p. 170): :

A propósito, entendemos que, em regra, o Código de Defesa do Consumidor aplica-se às relações que envolvem fundos de investimento, nos termos dos acórdãos relacionados, não obstante haver argumentos em sentido contrário, baseado no fato de que, sendo investimento, não há caracterização de consumo. ${ }^{35}$

Para o ingresso em fundos de investimentos, a CVM exige dos investidores a assinatura do termo de adesão e ciência de risco ${ }^{36}$, atestando o conhecimento de riscos inerentes às operações do fundo, como a existência de fatores econômicos do mercado doméstico e internacional que fogem à mão da gestão, e as estratégias de crédito e alavancagem do fundo; fatores que podem afetar a rentabilidade e os prazos de resgate (liquidez) do fundo. Ademais, as

\footnotetext{
${ }^{35}$ Página 170 Responsabilidade civil do administrador e do gestor de fundos de investimento

${ }^{36}$ Art. 25, I-CVM 555.
} 
informações relativas ao fundo, como a lâmina e sua regulamento são disponibilizados no site da CVM.

\subsection{Jurisprudência sobre a responsabilidade do gestor de fundos de investimentos}

PROCESSO ADMINISTRATIVO SANCIONADOR CVM $\mathbf{n}^{\circ}$ RJ2012/6987 $7^{37}$

Trata-se de caso em que a gestora de fundo de investimento em cotas do tipo previdenciário (em investimentos de renda fixa) foi considerada culpada por não ter agido de forma diligente ao infringir os limites de concentração por ativos previstos em seu regulamento.

A Agregga Investimentos Ltda. geria os dois fundos em questão, o FIC e o fundo investido. Ambos voltados para investidores qualificados, com aplicação mínima de R\$1.000.000,00. Desta forma, o fundo PREVTRUST (FIC) alocava 95\% de sua carteira no fundo máster - Fundo de Investimento Renda Fixa Crédito Privado Portfólio MASTER I.

De acordo com seu regulamento, o fundo PREVTRUST não poderia investir mais que $20 \%$ de sua carteira em ativos relativos a direitos creditórios. Todavia, o Fundo MASTER I alocava aproximadamente $70 \%$ de seu patrimônio no Coral FIDC Multisetorial. Logo, o PREVTRUST estaria investindo indiretamente mais que $60 \%$ de sua carteira em ativos de direitos creditórios, descumprindo as disposições de limite de exposição por ativos dessa categoria imposta em seu regulamento.

\footnotetext{
${ }^{37}$ Disponível em <http://www.cvm.gov.br/export/sites/cvm/sancionadores/sancionador/anexos/2014/20141118_PAS R J20126987.pdf>. Acesso em 14.06.2019.
} 
O defesa da gestora argumentou que o Fundo não estaria obrigado a obedecer a limitação de seu regulamento que limitava em $20 \%$ a alocação da carteira em ativos de direitos creditórios pelo fato do fundo ser compostos por investidores qualificados, à luz do Art. 109 da I-CVM 409. Este entendimento não foi acatado pela diretora Ana Dolores Moura Carneiro de Novaes, que decidiu no sentido de que houve claro descumprimento do dever de diligência pela gestora ao não observar que estaria provocando o desenquadramento ativo do fundo e expondo o capital dos quotistas para além do limite contratado, resultando em perdas expressivas de $42,64 \%$ do patrimônio total do PREVTRUST.

\section{PROCESSO ADMINISTRATIVO SANCIONADOR CVM $\mathbf{n}^{\mathbf{0}}$ RJ2015/990938}

O processo analisou a ocorrência de operações fraudulentas no âmbito da gestão do fundo de pensão de funcionários dos Correios - o POSTALIS (Instituto de Seguridade Social dos Correios e Telégrafos) - realizadas pelo diretor (e único sócio) da Atlântica Administração de Recursos Ltda. O patrimônio do POSTALIS, segundo seu regulamento, deveria ser alocado em ao menos $80 \%$ de títulos de dívida externa da União.

Nesse sentido, a operação de fraude foi constituída na venda dos títulos de dívida externa brasileira para a aquisição de duas notas (credit linked notes) lastreadas em títulos da dívida da Venezuela, Argentina e Brasil, o que por sua vez gerou um desenquadramento expressivo do POSTALIS, alocando apenas 2,13\% de seu patrimônio em títulos da dívida da União.

\footnotetext{
${ }^{38}$ Disponível em $<$ http://www.cvm.gov.br/export/sites/cvm/sancionadores/sancionador/anexos/2017/RJ20159909_Fabri zio_Dulcetti.pdf $>$ Acesso em 14.06.2019.
} 
As notas adquiridas através do UBS AG representavam riscos elevados de calote (default) - 70\% e 75\% para os títulos de Argentina e Venezuela, respectivamente --, fato que por si só já levantaria suspeitas, uma vez que a operação tinha grandes chances de prejudicar a aposentadoria dos quotistas do fundo. Não obstante, a investigação conduzida pela administradora do fundo (BNY Mellon) teria encontrado indícios claros de sobrepreço na aquisição das referidas notas, resultando em prejuízos na esfera de US\$79.000.000,00.

O diretor relator Gustavo Borba condenou o diretor responsável pela gestão do fundo ao pagamento de multa no valor de $\mathrm{R} \$ 438.837 .747,75$. Em seu voto, apesar de mencionar a quebra dos deveres de diligência e lealdade pelo gestor, o diretor optou por enquadrar a atuação do gestor como operação fraudulenta ${ }^{39}$, entendendo que a falta para com os deveres teria sido meios para efetivar a conduta de maior gravidade.

\footnotetext{
${ }^{39}$ ICVM 8, Art. $1^{\text {o } ~ I ~-~ c: ~ o p e r a c ̧ a ̃ o ~ f r a u d u l e n t a ~ n o ~ m e r c a d o ~ d e ~ v a l o r e s ~ m o b i l i a ́ r i o s, ~ a q u e l a ~ e m ~ q u e ~ s e ~}$ utilize ardil ou artifício destinado a induzir ou manter terceiros em erro, com a finalidade de se obter vantagem ilícita de natureza patrimonial para as partes na operação, para o intermediário ou para terceiros;
} 


\section{CONCLUSÃO}

A experiência econômica mundial mostra que via de regra o desenvolvimento de uma economia traz consigo políticas de juros baixos, quando não negativos.

Tais medidas buscam desestimular o investidor médio a guardar dinheiro, ou a realizar aplicações em títulos atrelados aos juros públicos, estimulando a aplicação do capital poupado em valores mobiliários relacionados às atividades econômicas reais e fomentando o crescimento da economia.

No Brasil, a instabilidade política exerce grande peso sobre o processo de estabilização econômica de longo prazo. Assim, não é possível analisar cenários futuros com a precisão necessária, mas gostaríamos de acreditar que este processo está em curso e que em algum momento naturalmente será consolidado.

Atualmente, apesar de um pouco longe da estabilidade completa, já nos aproximamos dos juros baixos, com a taxa SELIC em sua mínima histórica e viés de baixa. Assim, como nos anos subsequentes à aprovação do Plano Real, é possível identificar medidas que, mais uma vez, podem estimular o surgimento de novos investimentos e, por consequência, diversificar e aumentar a indústria de fundos de investimento no país.

Dessarte, é imprescindível compreender melhor os deveres e responsabilidades dos gestores de fundos, visando esclarecer os limites e os objetivos de sua atuação à luz da legislação composta pelas Instruções ${ }^{\circ} 555$ e 558 da CVM e da experiência de mercado da Lei das S.A.

Com esse propósito que o presente estudo foi desenvolvido, buscando compreender melhor como esses agentes podem operar de forma transparente $\mathrm{e}$ leal aos seus quotistas, contribuindo para criar condições mais equitativas de mercado. 
Nesse sentido, analisamos a legislação produzida e os papéis da CVM e ANBIMA nos aspectos de regulação e autorregulação dos fundos de investimento. Em seguida buscamos entender melhor a aplicação dos deveres de diligência e lealdade e seus subprincípios aplicados à gestão dos fundos. E, ao final, analisamos questões relativas à responsabilidade do gestor, trazendo jurisprudências do STJ e precedentes da CVM.

Sobre este último ponto, entendemos que vale mencionar a necessidade de se reproduzir em lei uma definição do legislador sobre a responsabilidade do gestor. Embora acreditamos em um sistema hibrido de responsabilidade - com tendências à responsabilização objetiva; as Instruções da CVM não são cristalinas sobre este tema. Ademais, em extensa pesquisa jurisprudencial não encontramos também uma consolidação de entendimento dos julgadores da autarquia sobre o assunto.

Embora a doutrina majoritária defenda a responsabilidade subjetiva da atividade de gestão de fundos de investimento, acreditamos que a proteção do investidor decorre da lei, não podendo ele ser prejudicado por práticas ilegais de gestão que fogem à álea do mercado. Enfim, uma definição interpretativa da norma pela própria autarquia também seria positiva para um ambiente de maior segurança jurídica, permitindo a previsibilidade de expectativas do investidor sobre a atuação do gestor. 


\section{Bibliografia}

FILHO, Alfredo Lamy; PEDREIRA, José Luiz Bulhões. A Lei das S.A.: Parte III - Pareceres. Rio de Janeiro: Renovar, 1996, v. 2.

FILHO, Alfredo Lamy; PEDREIRA, José Luiz Bulhões (Coords.). Direito das Companhias. Rio de Janeiro: Forense, 2017. $2^{\mathrm{a}}$. ed.

FILHO, Calixto Salomão. O Novo Direito Societário. Rio de Janeiro: Malheiros Editores, 2011. 4 . ed.

CARVALHO, Mário Tavernard Martins de. Regime jurídico dos fundos de investimento. Belo Horizonte: UFMG, 2012.

CARVALHOSA, Modesto; PARENTE, Norma Jonseen. Tratado de Direito Empresarial: mercado de capitais. São Paulo: RT, 2016.

EIZIRIK, Nelson et al. Mercado de Capitais: regime jurídico. Rio de Janeiro: Renovar, 2008.

EIZIRIK, Nelson. Temas de Direito Societário. São Paulo: RENOVAR, 2005 STOCO, Rui. Tratado de Responsabilidade Civil: Doutrina e Jurisprudência. $8^{\mathrm{a}}$ ed.. São Paulo: Editora Revista dos Tribunais, 2011.

Venosa, Sílvio de Salvio. Direito Civil: contratos em espécie e responsabilidade civil. São Paulo: Atlas, 2001, v. 3.

FREITAS, Bernardo Vianna; VERSIANI, Fernanda Valle. (Coords.). Fundos de Investimento - Aspectos Jurídicos, Regulamentares e Tributários. São Paulo: Quartier Latin, 2015. 
LOPES, Miguel Maria de Serpa. Curso de Direito Civil. $2^{\mathrm{a}}$ ed.. Rio de Janeiro: Freitas Bastos, 1962, v. 5.

MARTINS NETO, Carlos. A responsabilidade do cotista de fundo de investimento em participações. São Paulo: Almedina, 2017.

PARENTE, Flávia. O dever de diligência dos administradores de Sociedades Anônimas. Rio de Janeiro: Renovar, 2005.

PAVIA, Eduardo Cherez. Fundos de Investimento: estrutura jurídica e agentes de mercado como proteção de investimento. São Paulo: Quartier Latin, 2016.

PERRICONE, Sheila. A política de investimento e a responsabilidade dos administradores. Revista do Direito Bancário, do Mercado de Capitais e da Arbitragem, Arnoldo Wald (coord.), ano 4, no ii, São Paulo, Ed. RT, jan. - mar. 2001.

ROCHA, Tatiana Nogueira da. Fundos de investimento e o papel do administrador: a indústria de fundos no mercado brasileiro e a liberdade para agir, os poderes e obrigações os seus administradores. São Paulo: Textonovo, 2003.

BRIGAGÃO, Pedro Henrique Castello. A administração de companhias e a bussiness judgment rule: uma análise à luz do direito brasileiro. Rio de Janeiro. 2014. 191 p. Monografia (Bacharelado em Direito) Departamento de Direito da PUC-Rio.

DOMINGUES, Laura Moreira. Uma análise dos deveres e responsabilidades de administradores e gestores de fundos de investimento. Rio de Janeiro, 2016. 74p. Monografia (Bacharelado em Direito) Departamento de Direito da FUNDAÇÃO GETULIO VARGAS. 
RAGAZZI, Ana Paula Primeiro presidente da CVM descreve evolução do mercado.

Disponível

em

<https://www1.folha.uol.com.br/mercado/2018/08/primeiro-presidente-da-

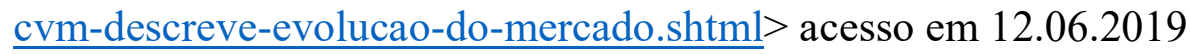

BERTÃO, Naiara. Juros futuros caem novamente para novos recordes de baixa.

Disponível em $\quad<$ https://valorinveste.globo.com/mercados/rendavariavel/bolsas-e-indices/noticia/2019/05/30/juros-futuros-caem-novamentepara-novos-recordes-de-baixa.ghtml>. Acesso em 10.06.2019.

LEITE, Carlos Alexandre Corrêa; XAVIER, Yanko Marcius de Alencar; ALVES, Fabrício Germano. Código de Defesa do Consumidor aplicado aos fundos de investimento: deveres e responsabilidade do administrador. Disponível em $<\underline{\text { https://revistajuridica.presidencia.gov.br/index.php/saj/article/view/1114>. }}$. Acesso em 13.06.2019.

BLOG Vérios. Disponível em $<$ https://verios.com.br/blog/page/2/> Acesso em 14.06.2019.

BRASIL. Lei $N^{o}$ 10.406, de 10 de Janeiro de 2002. Disponível em $<$ http://www.planalto.gov.br/ccivil_03/leis/2002/110406.htm>.Acesso em 10.06.2019.

BRASIL. Lei $n^{o}$ 4.728, de 14 de Julho de 1965. Disponível em $<$ http://www.planalto.gov.br/ccivil_03/leis/L4728.htm> Acesso em 01.06.2019. BRASIL. Lei $\mathrm{n}^{\mathrm{o}}$ 6.404, de 15 de Dezembro de 1976. Disponível em $<$ http://www.planalto.gov.br/ccivil_03/leis/16404consol.htm $>$ Acesso em 02.06.2019. 
BRASIL. Superior Tribunal de Justiça. Súmula $n^{o}$ 297. Disponível em $<\underline{\text { https://ww2.stj.jus.br/docs internet/revista/eletronica/stj-revista-sumulas- }}$ 201123 capSumula297.pdf>. Acesso em 10.06.2019.

BRASIL. Comissão de Valores Mobiliários. Audiência Pública para a Instrução $\mathrm{n}^{\mathrm{o}} 555 . \quad$ Disponível em $<$ http://www.cvm.gov.br/audiencias_publicas/ap_sdm/2014/sdm0414.html $>$. Acesso em 02.06.2019.

BRASIL. Comissão de Valores Mobiliários. Audiência Pública para a Instrução $\mathrm{n}^{\mathrm{o}} \quad 558 . \quad$ Disponível em $<$ http://www.cvm.gov.br/audiencias_publicas/ap_sdm/2011/sdm1411.html $>$. Acesso em 02.06.2019.

BRASIL. Comissão de Valores Mobiliários. Regulamento do Fundo Dynamo $\begin{array}{llll}\text { Cougar } & \text { FIA. Disponível em }\end{array}$ $<$ http://cvmweb.cvm.gov.br/swb/default.asp?sg_sistema=fundosreg $>$. Acesso em 14.06.2019.

BRASIL. Comissão de Valores Mobiliários. Instrução nº 409. Disponível em $<$ http://www.cvm.gov.br/legislacao/instrucoes/inst409.html $>$ Acesso em 02.06.2019.

BRASIL. Comissão de Valores Mobiliários. Instrução no 555. Disponível em $<$ http://www.cvm.gov.br/legislacao/instrucoes/inst555.html $>$ Acesso em 02.06.2019.

BRASIL. Comissão de Valores Mobiliários. Instrução n ${ }^{\circ}$ 558. Disponível em

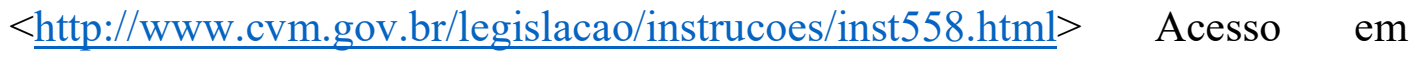
02.06.2019. 
BLOKHIN, Andriy. What is impact of Sarbanes-Oxley Act?. Disponível em <https://www.investopedia.com/ask/answers/052815/what-impact-did-

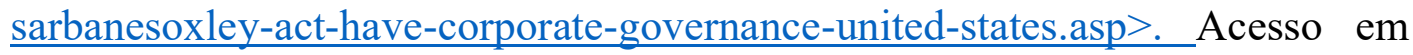
10.06.2019.

PATSURIS, Penelope. The Corporate Scandal Sheet. Disponível em $<\underline{\text { https://www.forbes.com/2002/07/25/accountingtracker.html\#181ec0bf57e8>. }}$ Acesso em 10.06.2019.

EUA. Sarbanes-Oxley Act of 2002. Disponível em $<\underline{\text { https://pcaobus.org/About/History/Documents/PDFs/Sarbanes_Oxley_Act_of }}$ 2002.pdf>. Acesso em 12.06.2019.

BRASIL. Supremo Tribunal Federal. ADI $\mathrm{n}^{\mathrm{o}}$ 2591. Disponível em $<\underline{\text { https://portal.stf.jus.br/processos/detalhe.asp? incidente }=1990517 .}>$ Acesso em 09.06.2019. 